\title{
Perspectives on the Terrestrial
} Organic Matter Transport and Burial along the Land-Deep Sea Continuum: Caveats in Our Understanding of Biogeochemical Processes and Future Needs

\section{OPEN ACCESS}

Edited by:

Sunil Kumar Singh,

Physical Research Laboratory, India

Reviewed by:

Arvind Singh,

Physical Research Laboratory, India

Tommaso Tesi,

National Research Council, Italy

Taichi Yokokawa,

Japan Agency for Marine-Earth

Science and Technology, Japan

*Correspondence:

Selvaraj Kandasamy

selvaraj@xmu.edu.cn

Specialty section

This article was submitted to Marine Biogeochemistry,

a section of the journal

Frontiers in Marine Science

Received: 20 July 2016 Accepted: 25 November 2016 Published: 15 December 2016

Citation:

Kandasamy S and Nagender Nath B (2016) Perspectives on the Terrestrial

Organic Matter Transport and Burial along the Land-Deep Sea Continuum:

Caveats in Our Understanding of

Biogeochemical Processes and

Future Needs. Front. Mar. Sci. 3:259.

doi: 10.3389/fmars.2016.00259

\author{
Selvaraj Kandasamy ${ }^{1 *}$ and Bejugam Nagender Nath ${ }^{2}$ \\ ${ }^{1}$ Paleoceanography and Paleoclimatology Group, State Key Laboratory of Marine Environmental Science, Department of \\ Geological Oceanography, Xiamen University, Xiamen, China, ${ }^{2}$ Geological Oceanography Division, National Institute of \\ Oceanography, Dona Paula, India
}

The natural carbon cycle is immensely intricate to fully understand its sources, fluxes and the processes that are responsible for their cycling in different reservoirs and their balances on a global scale. Anthropogenic perturbations add another dimension to such a complex cycle. Therefore, it is necessary to update the global carbon cycle by combining both natural and anthropogenic sources, fluxes and sinks along the land-sea continuum to assess whether these terms are currently in balance or not. Here, we review the export and burial rates of terrestrial organic carbon in the oceans to understand the issue of "missing terrigenous carbon" by comparing data- and model-based estimates of terrestrial carbon fluxes. Our review reveals large disparities between field data and model output in terms of dissolved and particulate organic carbon/matter (OC/OM) fluxes and their ratios, especially for Oceania and Arctic rivers, suggesting the need of additional investigations in these regions to refine terrestrial $\mathrm{OC}$ export budget. Based on our budgeting of global sources and sinks of OC with updated estimates of marine productivity and terrestrial $\mathrm{OM}$ burial rate, we find that the marginal sediments are key burial sites of terrestrial OM (TOM), which is consistent with earlier views of Berner (1982) and Hedges and Keil (1995). While about 60-80\% of TOM is remineralized in the margins, the estimated budget further reveals the ocean derived $\mathrm{OM}$ is efficiently remineralized than that of terrestrial $\mathrm{OM}$, emphasizing the need of further improvements of carbon burial estimation in the marine realm. When we look back in the past, higher terrestrial OC burial (by 50\%) in the deep ocean during the glacials than during the interglacials and suggests the subdued role of continental margins and an efficient transfer and preservation of OM from the shelf to deep sea in glacials. Based on the review of terrestrial and marine OM burial, we suggest some critical regions/ways that need to be investigated/addressed further, identification of new biogeochemical proxies and their grouping to better constrain the global carbon cycle along the land-deep sea continuum in future.

Keywords: carbon cycle, terrestrial organic carbon, fluvial export, carbon preservation, marine sediments, glacial-interglacial burial 


\section{BACKGROUND: MISSING TERRIGENOUS CARBON}

A number of natural agents such as rivers, winds, icebergs or sea ice and submarine groundwater transport dissolved and particulate material to the world oceans. Among these natural agents, rivers are responsible for the largest export of dissolved and particulate forms of terrestrial organic carbon/matter (OC/OM) to estuaries, and subsequently to continental shelves, slopes, and deep ocean basins, and act as key link in the global biogeochemical cycles of carbon and other nutrients (Chen, 2004; Bauer et al., 2013). Rivers export $\sim 0.25$ petagrams (Pg) of dissolved organic carbon (DOC) and $0.15 \mathrm{Pg}$ of particulate organic carbon (POC) from continents to the ocean annually (Hedges et al., 1997; $\sim 0.2 \mathrm{Pg}$ each of DOC and POC by Schlünz and Schneider, 2000). Such terrestrially-formed OC is a heterogeneous mixture of recent vascular plant detritus, associated soil OC, older fossil OC from meta-sedimentary rocks erosion, and black carbon (Hedges, 1992; Galy et al., 2007; Bianchi, 2011). Isotopic and biomarker data of this riverine OM suggested that much of them are soil-derived, nitrogenrich, fine particulate OM (Meybeck, 1982; Hedges et al., 1994). Nonetheless, the global burial flux of $\mathrm{OC}$ within modern marine sediments is estimated at 0.1-0.2 $\mathrm{Pg} \mathrm{C} \mathrm{yr}^{-1}$ (Berner, 1989; Hedges and Keil, 1995), which accounts for $\sim 0.1 \%$ of global primary production $\left(\sim 110 \mathrm{Pg} \mathrm{C} \mathrm{yr}^{-1}\right), \sim 0.2 \%$ of marine plankton photosynthesis $\left(\sim 50 \mathrm{Pg} \mathrm{C} \mathrm{yr}^{-1}\right)$ and indeed less than half of the input of total terrestrial OM by rivers alone (Bianchi, 2011). Consistently, recent calculations also estimated that only $\sim 30$ $35 \%$ of the OC being buried in marine sediments is of terrestrial origin (Burdige, 2005; Houghton, 2007). Ninety percent of the OC burial in the ocean occurs in deltaic and margin sediments and is associated with mineral particles largely of clay-silt sizes (Hedges and Keil, 1995). Moreover, this terrestrial OC associated with fine minerals of large surface area can be exchanged with marine OM as it enters the coastal ocean (Hedges et al., 1997; Keil et al., 1997). This export to burial offset of terrestrial OC implies that most terrigenous $\mathrm{OM}$ delivered to the oceans must be efficiently remineralized, and that the ocean is operating as a net heterotrophic system, accumulating less sedimentary OC than it receives via riverine input (Smith and Mackenzie, 1987; Blair and Aller, 2012). Therefore, the geochemical conundrum of 'missing terrigenous carbon' is still an unresolved issue of the global carbon cycle (Hedges and Keil, 1995; Hedges et al., 1997; Bianchi, 2011).

Given that improvements of models of biogeochemical cycling and Earth surface evolutionary processes largely rely on the understanding of the fate of terrestrial organic carbon that is delivered to oceans by rivers (Berner, 2004; Blair and Aller, 2012) and to better understand the above mentioned paradox, here we review the transport of terrestrial organic carbon fluxes from land to the ocean and then briefly discuss the global organic carbon sources and sinks in the ocean. After the introduction (Section 1.1), Section 1.2 provides a short overview of global carbon cycle briefly addressing its potential sources and sinks with updates of carbon reservoirs and fluxes. Section 1.3 focuses on the global riverine organic fluxes by compiling available estimates with recalculation wherever it is necessary and comparing with modeled data. Section 1.4 addresses the role of Oceania in terrestrial organic carbon export and explains why we have large uncertainties in that region of the world. Section 1.5 addresses global carbon sources and sinks focusing to understand mismatches in the available budgets in terms of terrestrial sources and marine sinks. Section 1.6 emphasizes carbon burial in the marine realm. Section 1.7 provides additional directions of investigations in the future that might be appropriate to refine the terrestrial carbon export and burial budgets toward a better understanding of the global carbon cycle.

\section{GLOBAL CARBON CYCLE OVERVIEW: NATURAL AND PERTURBED}

Biogeochemical cycle of carbon constitutes feedbacks in the Earth's Climate System by altering carbon stocks and fluxes in different reservoirs, i.e., atmosphere, biosphere, hydrosphere, lithosphere and cryosphere, of the Earth (Hedges, 1992; Sarmiento and Gruber, 2002; Ciais et al., 2013). The global carbon cycle can thus be viewed as a series of carbon reservoirs in the Earth System that are connected via exchange of carbon fluxes (Figure 1). This cycle consists of two generalized domains: (i) a fast domain with large exchange fluxes and relatively rapid reservoir turnovers, which consists of carbon in the atmosphere (730 petagrams of carbon-Pg C; $1 \mathrm{Pg}=10^{15} \mathrm{~g}$ ), the ocean $(38,700 \mathrm{Pg} \mathrm{C})$, oceanic surface sediments (1750 Pg C) and on land in vegetation (550 Pg C), soils (1950 Pg C), and freshwaters $(1.7 \mathrm{Pg} \mathrm{C}$ ) (Figure 1). Reservoir turnover times ( $\mathrm{t}$ ), defined as reservoir mass of carbon divided by the exchange flux, range from a few years for the atmosphere to decades to millennia for the major carbon reservoirs of the land vegetation $(t=$ 0 years) and soil (10-10000 years) and the various domains in the ocean ( $\sim 400-5000$ years); (ii) a slow domain consists of the huge carbon stores in rocks and sediments $(15,000,000$ $\mathrm{Pg} \mathrm{C})$ and these reservoirs exchange carbon with the fast domain through volcanic emissions of $\mathrm{CO}_{2}(0.1 \mathrm{Pg} \mathrm{C})$, chemical weathering $(0.3 \mathrm{Pg} \mathrm{C})$ as well as via erosion and sediment formation on the sea floor (Sundquist, 1986). Turnover times of these geological reservoirs are on millennial timescales $(10,000$ years or longer). Natural exchange fluxes between these two domains of the carbon cycle are relatively small $(<0.4 \mathrm{Pg}$ $\mathrm{C} \mathrm{yr}^{-1}$; Figure 1) and constant over the last few centuries that is similar to the flux exchanges during the Holocene and beyond.

Nevertheless, since the beginning of the Industrial Era (i.e., $1750 \mathrm{AD}$ ), humans are producing energy by burning the fossil fuels (coal, oil and gas; Figure 1), a process that is releasing large amounts of $\mathrm{CO}_{2}$ into the atmosphere (Sarmiento and Gruber, 2002). The cumulative total $\mathrm{CO}_{2}$ emissions from fossil fuel burning to the atmosphere amount to $365 \pm 30 \mathrm{PgC}$ with a flux of $7.8 \pm 0.6 \mathrm{Pg} \mathrm{C} \mathrm{yr}^{-1}$ (Figures 1, 2). This rising atmospheric $\mathrm{CO}_{2}$ content seems to induce an effective exchange of fluxes between the atmosphere and its two major sinks, the land and oceans. The anthropogenic $\mathrm{CO}_{2}$ added to the atmosphere and the way it is currently apportioned to the land, air, inland water, coastal ocean and the open ocean, are illustrated in the simple diagram of global 


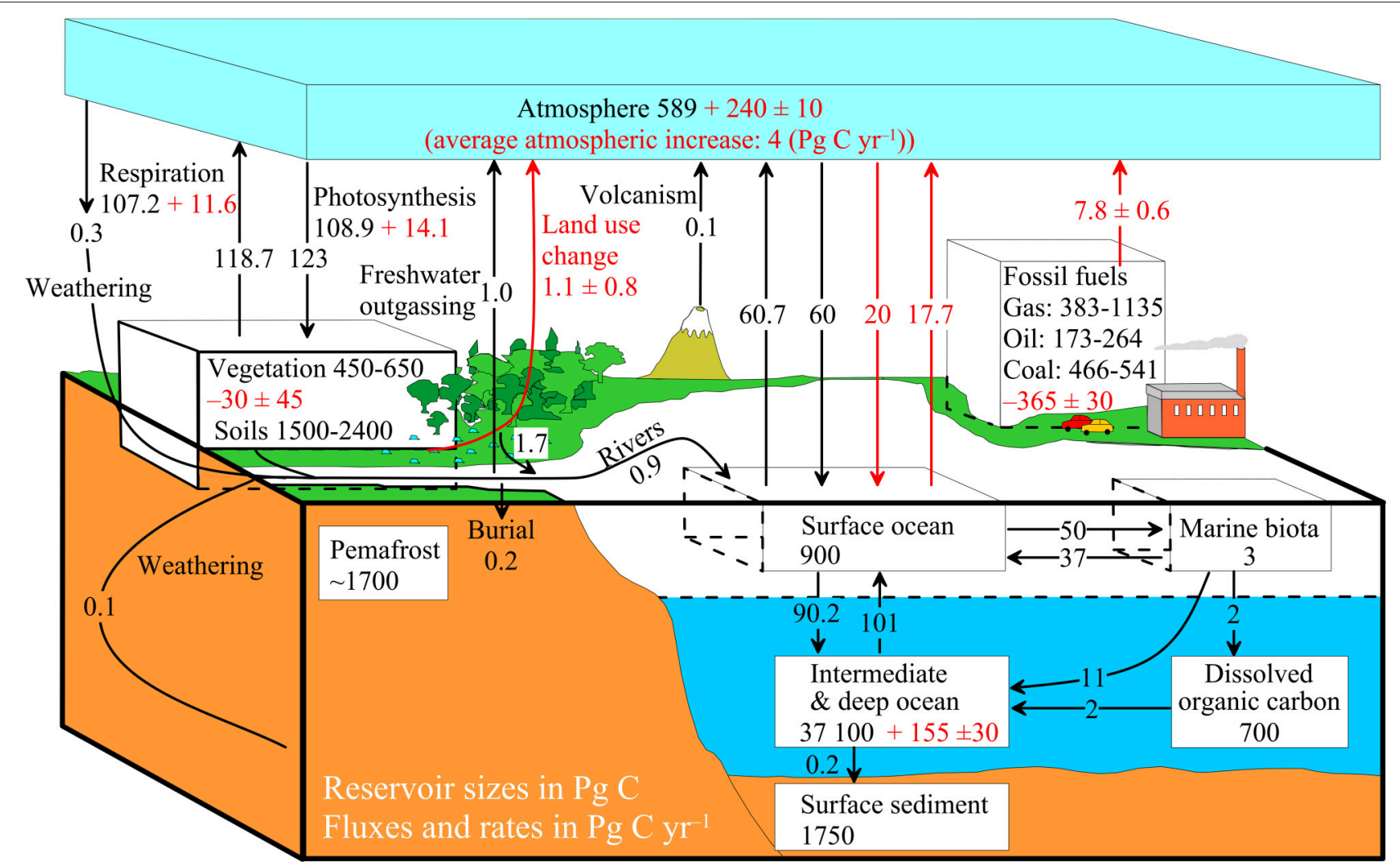

FIGURE 1 | Simplified diagram of the global carbon cycle. Numbers denote reservoir mass, also called "carbon stocks" in Pg C $\left(1 \mathrm{Pg} \mathrm{C}=10^{15} \mathrm{~g}\right.$ C) and annual carbon exchange fluxes (in $\mathrm{Pg} \mathrm{C} \mathrm{yr}^{-1}$ ) between the atmosphere and its two major sinks, the land and ocean. Black numbers and arrows indicate reservoir mass and exchange fluxes estimated for the time prior to the Industrial Era, about 1750. Red arrows and numbers indicate annual "anthropogenic" fluxes averaged over the 2000-2009 time period. These fluxes are a perturbation of the carbon cycle during Industrial Era post 1750. Red numbers in the reservoirs represent cumulative changes of anthropogenic carbon over the Industrial Period 1750-2011. The diagram model is taken from Sarmiento and Gruber (2002) and all numbers of stocks and fluxes are reproduced from Ciais et al. (2013).

carbon budget cycle (Figure 2). The average fossil-fuel emissions during 2000-2010 AD are estimated at $7.9 \pm 0.5 \mathrm{Pg} C$ (Bauer et al., 2013; Ciais et al., 2013; Regnier et al., 2013). The uptake flux of anthropogenic $\mathrm{CO}_{2}$ by the terrestrial ecosystem is estimated to

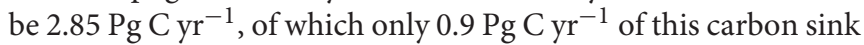
is actually sequestered in biomass and soil of land ecosystem, as 1.0 $\mathrm{Pg} \mathrm{C} \mathrm{yr}^{-1}$ is returned to the atmosphere by $\mathrm{CO}_{2}$ outgassing owing to land-use changes, and a similar amount $\left(0.95 \mathrm{Pg} \mathrm{C} \mathrm{yr}^{-1}\right)$ is exported to the aquatic system (Figure 2). The anthropogenic carbon delivered to freshwater (inland water and estuary) (1.0 Pg $\left.\mathrm{C} \mathrm{yr}^{-1}\right)$ is partly outgassed to the atmosphere as $\mathrm{CO}_{2}(0.55 \mathrm{Pg} \mathrm{C}$ $\left.\mathrm{yr}^{-1}\right)$, partly sequestered in the sediment $\left(0.35 \mathrm{Pg} \mathrm{C} \mathrm{yr}^{-1}\right)$, and partly exported to coastal ocean $\left(0.1 \mathrm{Pg} \mathrm{C} \mathrm{yr}^{-1}\right)$. Enhanced rock weathering due to human perturbation also contributes $0.1 \mathrm{Pg}$ $\mathrm{C} \mathrm{yr}^{-1}$ to the freshwater ecosystem. The continental shelf also contributed to the atmospheric $\mathrm{CO}_{2}$ budget $\left(0.2 \mathrm{Pg} \mathrm{C} \mathrm{yr}^{-1}\right.$ air-sea uptake, $0.15 \mathrm{Pg} \mathrm{C} \mathrm{yr}^{-1}$ sequestered in the sediment, and $0.05 \mathrm{Pg} \mathrm{C}$ $\mathrm{yr}^{-1}$ in the water column). Therefore, the net land anthropogenic $\mathrm{CO}_{2}$ uptake from terrestrial, freshwater and estuarine aquatic ecosystems is only about $1.35 \mathrm{Pg} \mathrm{C} \mathrm{yr}^{-1}$, while ocean uptake of anthropogenic $\mathrm{CO}_{2}$ is about $2.5 \mathrm{Pg} \mathrm{C} \mathrm{yr}^{-1}$, closely similar to a value of $2.3 \mathrm{Pg} \mathrm{C} \mathrm{yr}^{-1}$ averaged over the 2000-2009 time period in Figure 1.

The bulk carbon input to inland water is estimated as $2.8 \mathrm{Pg} \mathrm{C}$ $\mathrm{yr}^{-1}$, and composed of four sources, excluding the source from physical erosion. They are mainly coming from soil (1.9 Pg C

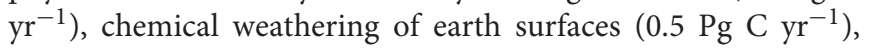
photosynthetic carbon fixation within inland waters $(0.3 \mathrm{Pg} \mathrm{C}$ $\left.\mathrm{yr}^{-1}\right)$ and sewage $\left(0.1 \mathrm{Pg} \mathrm{C} \mathrm{yr}^{-1}\right)$. The fate of these sources of carbon into inland waters are removed through $\mathrm{CO}_{2}$ and $\mathrm{CH}_{4}$ outgassing with amount of 1.1 and $0.1 \mathrm{Pg} \mathrm{C} \mathrm{yr}^{-1}$, exported to estuary of $1.3 \mathrm{PgC} \mathrm{yr}^{-1}$ and buried in sediment of $0.6 \mathrm{PgC}^{-1}$. In addition to carbon export from upland water, the estuary also receives the carbon input from adjacent marsh ecosystems with $0.3 \mathrm{Pg} \mathrm{C} \mathrm{yr}^{-1}$. Recent studies have suggested that estuaries emit around $0.25 \mathrm{Pg} \mathrm{C} \mathrm{yr}^{-1} \mathrm{CO}_{2}$ to the atmosphere, while $0.1 \mathrm{Pg} \mathrm{C}$ $\mathrm{yr}^{-1}$ is buried in sediment and $0.95 \mathrm{Pg} \mathrm{C} \mathrm{yr}^{-1}$ is exported to the continental shelf. The continental shelf acts as a sink as it is responsible for the net atmospheric $\mathrm{CO}_{2}$ uptake flux of $0.2 \mathrm{Pg}$ $\mathrm{C} \mathrm{yr}^{-1}$. This flux, together with the carbon flux from estuary, is $1.15 \mathrm{Pg} \mathrm{C} \mathrm{yr}^{-1}$, of which $0.75 \mathrm{Pg} \mathrm{C} \mathrm{yr}^{-1}$ carbon is exported to open ocean and $0.35 \mathrm{Pg} \mathrm{C} \mathrm{yr}^{-1}$ is accumulated in sediment 


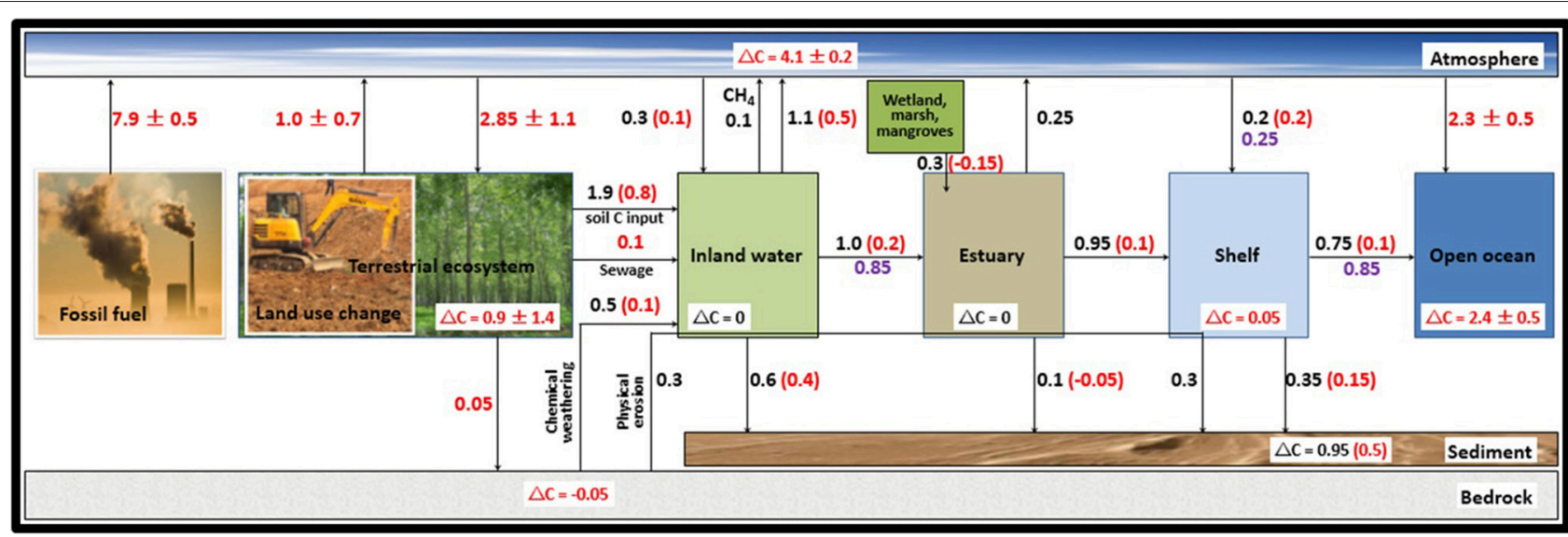

FIGURE 2 | Simplified schematic of the global carbon budget and its anthropogenic perturbation. All fluxes are in $\mathrm{Pg} C \mathrm{yr}{ }^{-1}, \mathrm{rounded} \mathrm{to} \pm 0.05 \mathrm{Pg} \mathrm{C} \mathrm{yr}^{-1}$ and represent the total carbon fluxes (organic and inorganic carbon). Arrows indicate direction of flux and $\Delta \mathrm{C}$ refer to carbon accumulation within each reservoir. The numbers in the red color are the budget of anthropogenic $\mathrm{CO}_{2}$ and numbers in the purple color are taken from Bauer et al. (2013). This figure is modified from Regnier et al. (2013).

(Figure 2). Based on the above overview, even though we have the feeling that we fairly understood and resolved both natural and perturbed stages of the global carbon cycle, it seems obvious that the well-known caveat in the scientific understanding of the natural carbon cycle, the "missing terrigenous carbon" in the sediments of continental margin, persists till date. Nonetheless, new results available now provide additional clues to narrow the gap in the caveat between the riverine export of terrestrial organic carbon and its burial in marine sediments.

\section{GLOBAL RIVERINE ORGANIC CARBON FLUXES}

To understand the organic carbon budgets for the global ocean, we compiled previously estimated data of terrestrial organic carbon fluxes from the literature. Table 1 shows global estimates of dissolved, particulate and total organic carbon (DOC, POC, and TOC) fluxes from land to the sea through rivers annually.

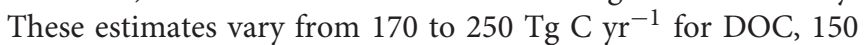
to $282 \mathrm{Tg} \mathrm{C} \mathrm{yr}^{-1}$ for POC and from $\sim 335$ to $514 \mathrm{Tg} \mathrm{C} \mathrm{yr}^{-1}$ for TOC (Table 1). We have not included earlier estimates in Table 1 and those readers who are interested in estimates prior to 1990s, please refer to Hope et al. (1994), Ludwig et al. (1996), and Schlünz and Schneider (2000) and references therein. If we consider those estimates prior to 1990s, then the TOC flux for instance varied from 30 to $1000 \mathrm{Tg} \mathrm{C} \mathrm{yr}^{-1}$ (see Schlünz and Schneider, 2000 for more details). The mean ( \pm standard deviation) fluxes of worldwide input of terrestrial DOC, POC, and TOC to the ocean are $212( \pm 29), 203( \pm 41)$ and $419( \pm 61)$ $\mathrm{Tg} \mathrm{C} \mathrm{yr}^{-1}$, respectively (Table $\mathbf{1}$ ). These averaged fluxes for POC and TOC are consistent with estimates made by Meybeck and Vörösmarty (1999), Schlünz and Schneider (2000), and Huang et al. (2012) (Table 1).

Although dissolved inorganic carbon (DIC) and particulate inorganic carbon (PIC) are certainly important fluxes to balance
TABLE 1 | Estimations of the global riverine organic carbon input to the oceans after 1990s.

\begin{tabular}{lcccl}
\hline References & DOC & POC & TOC & Data/Model \\
\hline Degens et al., 1991 & - & - & 335 & Data \\
Spitzy and Ittekkot, 1991 & - & - & 500 & Data \\
Meybeck, 1993 & 198 & 170 & 368 & Data \\
Ludwig et al., 1996 & 205 & 173 & 378 & Model \\
Hedges et al., 1997 & 250 & 150 & 400 & Data \\
Meybeck and Vörösmarty, & 215 & 205 & 420 & Data \\
1999 & & & & \\
Schlünz and Schneider, 2000 & 219 & 215 & 434 & Data \\
McKee, 2003 & 250 & 250 & 500 & Data \\
Seitzinger et al., 2005 & 170 & 197 & 367 & Model \\
Dai et al., 2012 & 170 & - & - & Data and extrapolation \\
Huang et al., 2012 & 206 & 188 & 394 & Data and extrapolation \\
Huang et al., 2012 and & $239 \$$ & $282^{\$}$ & $514 \$$ & Data and recalculation \\
Milliman and Farnsworth, 2011 & & & & \\
Mean & 212 & 203 & 419 & \\
SD & 29 & 41 & 61 & \\
\hline & & & &
\end{tabular}

DOC, dissolved organic carbon; POC, particulate organic carbon; TOC, total organic carbon. All values are in teragrams carbon per year $\left(\operatorname{TgC~} y r^{-1} ; \mathrm{Tg}=10^{12} \mathrm{~g}\right)$. ${ }^{\$}$ These numbers have been recalculated based on the POC/TSM data of Huang et al. (2012) using the revised sediment discharge data of Milliman and Farnsworth (2011).

sources and sinks of the global carbon cycle, in this study to reconstruct the organic carbon budget, we have used only the DOC, POC, and TOC and have not included DIC and PIC in our estimates. For the present review, we reproduced DOC fluxes from Dai et al. (2012), which is considered as the most recent DOC flux estimation based on the most up-to-date literature data. However, different values seen in Table 1 (170 vs. 239 Tg $\mathrm{C} \mathrm{yr}^{-1}$; see Table 2 for the detailed calculation) are due

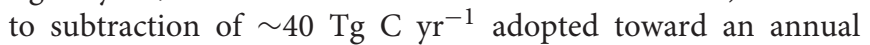
DOC removal rate during its transport into the Arctic and 
TABLE 2 | Data-based, continent-wise estimates of terrestrial DOC, POC, and TOC.

\begin{tabular}{|c|c|c|c|c|c|c|c|c|}
\hline Continents & $\begin{array}{l}\text { Water discharge } \\
\qquad\left(\mathrm{km}^{3} \mathrm{yr}^{-1}\right)\end{array}$ & $\begin{array}{c}\text { DOC concentration } \\
\left(\mathrm{mg} \mathrm{L}^{-1}\right)\end{array}$ & $\begin{array}{c}\text { DOC flux } \\
\left(\operatorname{Tg~C~yr}^{-1}\right)\end{array}$ & $\begin{array}{l}\text { Sediment load } \\
\text { (Mt yr-1) }\end{array}$ & $\begin{array}{c}\text { POC/TSM } \\
\text { concentration \% }\end{array}$ & $\begin{array}{c}\text { POC flux } \\
\left(\operatorname{Tg~C~yr}^{-1}\right)\end{array}$ & $\begin{array}{c}\text { TOC flux } \\
\left(\operatorname{Tg~C~yr}^{-1}\right)\end{array}$ & DOC/POC ratio \\
\hline Africa & 3596 & $8.03 \pm 1.89$ & $28.9 \pm 6.8$ & 1500 & 1.27 & 19.1 & 48.0 & 1.51 \\
\hline Arctic & 3658 & $8.36 \pm 0.72$ & $30.6 \pm 2.6$ & 150 & $2.90^{\$}$ & $6.0^{\$}$ & $30.0^{\$}$ & $5.10^{\$}$ \\
\hline Asia & 9838 & $5.32 \pm 0.29$ & $52.4 \pm 2.8$ & 5300 & 1.23 & 65.2 & 117.6 & 0.80 \\
\hline Europe & 2162 & $7.74 \pm 0.64$ & $16.7 \pm 1.4$ & 850 & 1.04 & 8.8 & 25.5 & 1.90 \\
\hline Oceania & 592 & $4.76 \pm 1.60$ & $2.82 \pm 0.9$ & 7100 & 1.44 & 102.2 & 105.0 & 0.03 \\
\hline North America & 6271 & $4.22 \pm 0.13$ & $26.5 \pm 0.8$ & 1900 & 1.92 & 36.5 & 63.0 & 0.73 \\
\hline South America & 14828 & $5.47 \pm 1.85$ & $81.1 \pm 27.4$ & 2300 & 1.92 & 44.2 & 125.3 & 1.83 \\
\hline Global total/ average ${ }^{*}$ & 40586 & $6.27 \pm 1.02^{\star}$ & $239.0 \pm 34.2$ & 19100 & $1.67^{\star}$ & 282.0 & 514.4 & $1.70^{\star}$ \\
\hline
\end{tabular}

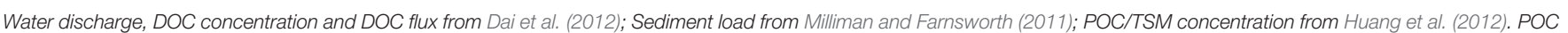
fluxes are recalculated using \%POC/TSM with the sediment load given here. ${ }^{\$}$ Concentrations and fluxes of POC for the Arctic continental rivers are taken from Rachold et al. (2004). ${ }^{\star}$ Global average.

estuaries/coastal ocean by Dai et al. (2012). On the other hand, we reestimated the POC flux using data given in Table 1 of Huang et al. (2012). We applied the same method described in Huang et al. (2012) for the estimation of the POC flux by correlating the \%POC in TSM with the concentration of TSM using the formula: $\mathrm{POC} \%=71.66 \times \mathrm{TSM}\left(10^{12} \mathrm{~g} \mathrm{yr}^{-1}\right)^{-0.78}$ for 32 tropical rivers. Huang et al. (2012) have interpolated their estimate for tropical rivers to global rivers based on the continent-wise sediment load. Nevertheless, we recalculated POC fluxes with updated continental sediment loads published in Milliman and Farnsworth (2011). In Huang et al. (2012), the sediment fluxes were calculated using the water balance and transport model of the University of New Hampshire (WBM/WTM; Syvitski et al., 2005). The global sediment load determined using WBM/WTM model was $12,610 \mathrm{Mt} \mathrm{yr}^{-1}$, which is equal to only $66 \%$ of the revised sediment load estimate of Milliman and Farnsworth (2011) (19,100 Mt $\mathrm{yr}^{-1}$; Table 2). We do separate Americas into North America and South America using different sediment loads, but with a similar \%POC/TSM data (see Table 2).

Since Huang et al. (2012) have not included fluxes from the Arctic rivers in their study, the concentration of POC and its flux for the Arctic rivers were taken from Rachold et al. (2004) (Table 2). Because of this recalculation, global as well as continental POC and TOC fluxes show differences between Huang et al. (2012) and our study. The mismatch comes mainly from $\sim 102 \mathrm{Tg} \mathrm{C} \mathrm{yr}^{-1}$ of POC obtained for Oceania because of a difference in sediment loads adopted in these two studies (485 vs. $7100 \mathrm{Mt} \mathrm{yr}^{-1}$; Table 2). Interestingly, this is the highest POC and TOC discharges obtained for Oceania so far and therefore this value needs a relook (see Section Role of Oceania in Terrestrial OC Export for more discussion). Figure 3 shows the magnitude of the different forms of carbon fluxes, expressed in relation to the major continental drainage regions. For the DOC transport, the order is South America $>$ Asia $>$ Africa $>$ North America $>$ Europe $>$ Oceania and for POC transport, the order is Oceania $>$ Asia $>$ South America $>$ North America $>$ Africa $>$ Europe (Figures 3A,B). Note that the values represent natural averages and do not account for human impact and the POC retention in reservoir. When compared to previously reported continent-wise
DOC and POC transport by Degens and Ittekkot (1985), the order for DOC transport is the same over the last $\sim 30$ years with the top transport being from South America and the least coming from Oceania; but the order do show a change with Oceania taking a top position for the transport of POC with Asia being the second highest (Figure 1B). One potential reason is the higher dam/reservoir POC trap in Asia than in Oceania (Vörösmarty et al., 2003; Walling, 2009), where short, steep mountainous rivers expedite almost $100 \%$ sediment and POC discharges to the surrounding ocean (Lyons et al., 2002; Selvaraj et al., 2015).

Seitzinger et al. (2005) used NEWS (Global Nutrient Export from Watersheds) models to estimate global nutrient export at the mouth of 5761 exoreic river basins, as a function of natural biogeophysical properties (such as land use, nutrients inputs, hydrology, etc.). The advantage of NEWS models is that these models enable comparison of riverine nutrient export by nutrient element, form, and source at regional, continental and global scales. To understand how far the data-based flux measurements can represent the terrestrial DOC, POC, and TOC export to the oceans, we compared fluxes estimated based on the measured data with that of the NEWS modeled output for different continents (Figure 3). Continent-wise DOC fluxes for example reveal that fluxes calculated using the measured river data are always lower than that of DOC fluxes predicted from NEWS models (Figure 1A). Except for Europe, for all remaining continents, the model predicted approximately 26 times higher than the data-based fluxes (Figure 3A). This mismatch is the highest for South America and Asia is the second highest, implying either that the measured field data of DOC concentrations currently available for flux estimate are likely insufficient to represent the continental-wise DOC fluxes or NEWS models may have overestimated DOC fluxes for all continents or both. Nevertheless, our recalculated POC fluxes for most continents lie within $20-30 \%$ of the NEWS model prediction (Figure 3B). In addition, data-based POC fluxes are more or less similar for continents such as Africa, Europe and South America, whereas Asia, Oceania and North America show comparatively higher POC fluxes than that of model prediction (Figure 3B). 


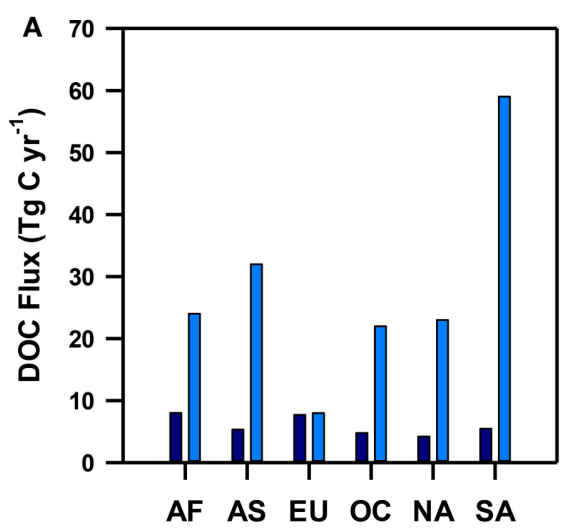

Continents
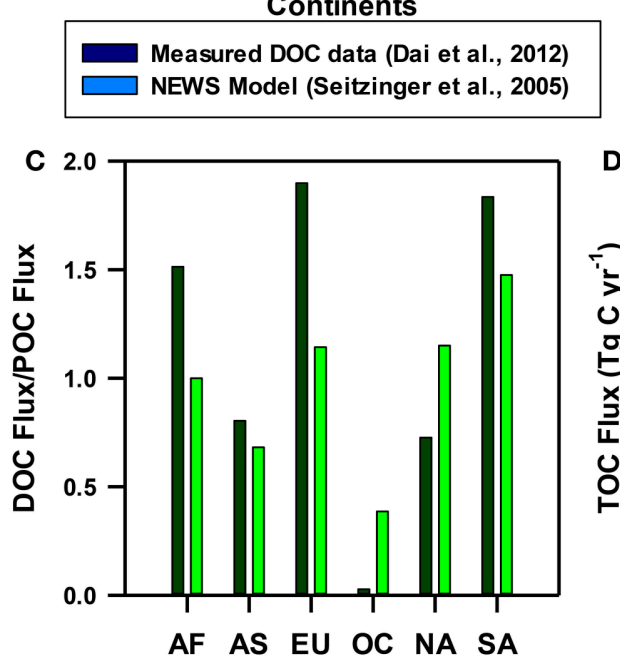

Continents

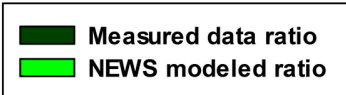

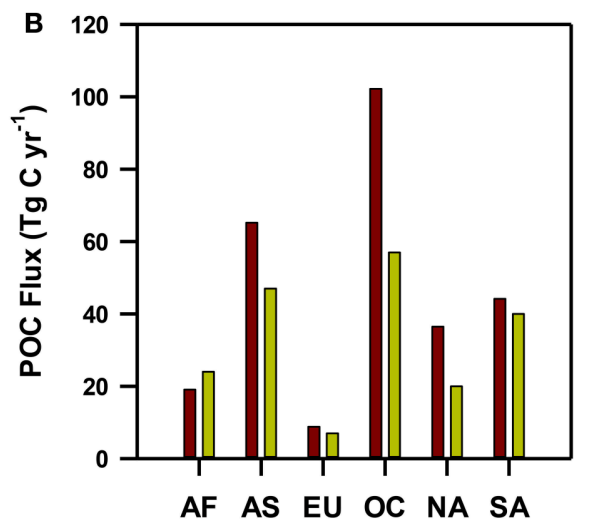

Continents

Recalculated POC data (This study) NEWS Model (Seitzinger et al., 2005)

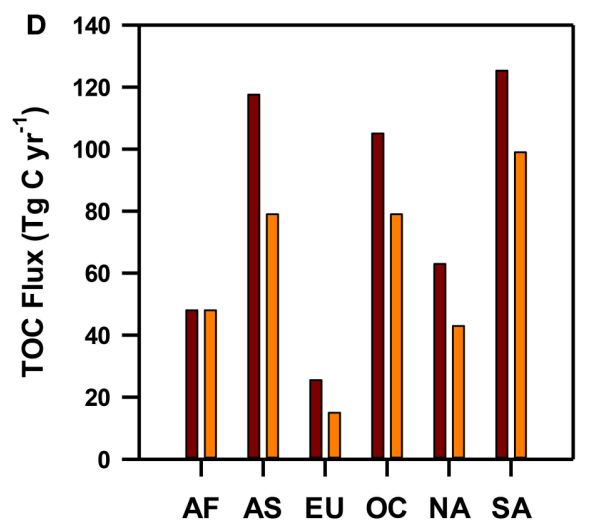

Continents

Measured data NEWS modeled data

FIGURE 3 | Continent-wise (A) spatial distribution of dissolved organic carbon (DOC) fluxes reproduced from Dai et al. (2012) (dark blue) compared with the predicted fluxes of NEWS (Global Nutrient Export from Watersheds) models from Seitzinger et al. (2005) (blue); (B) spatial distribution of particulate organic carbon (POC) fluxes recalculated from Huang et al. (2012) (dark red) compared with the NEWS predicted values from Seitzinger et al. (2005) (dark yellow); (C) DOC/POC fluxes ratios from the measured data (dark green) compared with similar ratios of NEWS models (light green); (D) spatial distribution of total organic carbon (TOC) fluxes recalculated in this study (dark red) compared with the POC fluxes predicted by NEWS models (dark orange). AF, Africa; AS, Asia; EU, Europe; OC, Oceania; NA, North America; SA, South America.

Conversely, global fluxes of DOC and POC (170 and $197 \mathrm{Tg}$

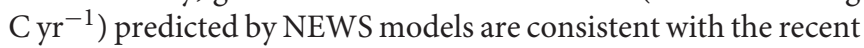
estimation of DOC discharges by Dai et al. (2012) and DOC and POC discharges by Huang et al. (2012) (Table 1), indicating that estimations using both river measured data and subsequent regional scale extrapolation and model predictions are consistent and supportive of each other, particularly on global scale. It is also evident from DOC/POC ratios of the measured data (1.13) and NEWS model prediction (0.97) because both maintain around one at global scale (without Arctic), but these ratios varied from 0.03 (Oceania) to 1.90 (Europe) in the measured data and 0.39 (Oceania) to 1.48 (South America) in the NEWS model prediction at continental scale (Figure 3C). The lowest $\mathrm{DOC} / \mathrm{POC}$ ratio of Oceania in the measured data is consistent with the lowest water discharge $\left(592 \mathrm{~km}^{3} \mathrm{yr}^{-1}\right)$, but the highest sediment load (7100 Mt yr ${ }^{-1}$ against the global sediment flux of 19,100 $\mathrm{Mt} \mathrm{yr}^{-1}$; Table 2), whereas the highest DOC/POC ratios of Arctic (5.10) and South America (1.83) are likely related to higher DOC than the POC fluxes of the Arctic rivers and the enormous discharge of Amazon, respectively, but such ratio with Europe perhaps attributed to low content of \%POC/TSM (1.04\%, which is a global mean mentioned in Huang et al., 2012) applied for the recalculation of POC flux in the present study (Table 2). Seitzinger et al. (2005) noted through NEWS-modeling of global fluxes of different forms of carbon that export of DOC and POC was roughly equal at both global and continental scales (Figure 1), though Oceania, Asia and Australia showed a higher proportion of POC than other continents and South America 
showed a higher proportion of DOC, consistent to the estimated flux from the measured data (Dai et al., 2012; Huang et al., 2012) and interpretations made here.

Similar to global and continental POC fluxes, TOC fluxes also show higher fluxes than previous estimates for Oceania, Asia and South America. The global TOC estimate of $514{\mathrm{Tg} \mathrm{C} \mathrm{yr}^{-1}}^{-1}$ obtained through recalculation in this study is similar to previous estimates published by Spitzy and Ittekkot (1991) and McKee (2003) (Table 1). However, our estimation is $\sim 120 \mathrm{Tg} \mathrm{C} \mathrm{yr}^{-1}$ higher compared to Huang et al. (2012) (394 $\mathrm{Tg} \mathrm{C} \mathrm{yr}^{-1}$ ). NEWS model also predicted TOC export of $367 \mathrm{Tg} \mathrm{C} \mathrm{yr}^{-1}$, which is similar to that of Ludwig et al. (1996) (380 $\mathrm{Tg} \mathrm{C} \mathrm{yr}^{-1}$ ) which was based on global spatial DOC and POC models. Closely similar TOC fluxes have also been obtained from the measured river data by Meybeck (1982) (395 $\mathrm{Tg} \mathrm{C} \mathrm{yr}^{-1}$ ) and through nonspatial estimate of $396 \mathrm{Tg} \mathrm{C} \mathrm{yr}^{-1}$ by Mackenzie et al. (1993). The consistency among these previous estimates implies that our recalculation somehow overestimated the global TOC flux in general, and Oceania, Asia and South America in particular (Figure 3D).

The Arctic Ocean receives $\sim 10 \%$ of the global river discharge from six large rivers (the Yukon and Mackenzie in North America and the Yenisey, $\mathrm{Ob}^{\prime}$, Lena and Kolyma in Eurasia) those draining a land area of approximately 20.5 million $\mathrm{km}^{2}$ (Rachold et al., 2004; McClelland et al., 2016). These rivers transport massive quantities of dissolved and particulate materials that reflect watershed sources and impact biogeochemical cycling in the ocean. In a previous study, Dittmar and Kattner (2003) estimated (DOC reaches concentrations of up to $1000 \mu \mathrm{M} \mathrm{C}$ ) the total amount of DOC discharged by rivers into the Arctic Ocean to be $18-26 \mathrm{Tg} \mathrm{C} \mathrm{yr}^{-1}$ and the number was similar to that of the DOC export from Amazon. The discharge of POC was however much lower with 4-6 Tg $\mathrm{yr}^{-1}$. Based on 9 years of depth-integrated, seasonally explicit sampling, McClelland et al. (2016) presented new estimates of particulate OC and nitrogen fluxes for the major Arctic rivers. They estimated that the six largest Arctic rivers export $\sim 3.1 \mathrm{Tg}$ of POC annually and their interpolation of this estimate for the entire pan-Arctic watershed to be $\sim 5.8 \mathrm{Tg}$ of POC, consistent with the previous estimates of Rachold et al. (2004) (Table 2). However, we have not included estimates for the Arctic rivers in Figure 1 mainly because of the following reasons: (a) although Arctic rivers transport huge quantities of DOC (21.3 $\mathrm{Tg} \mathrm{C} \mathrm{yr}^{-1}$; Table 2), it has been suggested that DOC in Arctic rivers is mostly refractory with little or no evidence of loss of DOC as it traverses the continental shelf (Dittmar and Kattner, 2003) and thus plays insignificant role in the biogeochemistry of the Arctic Ocean; (b) when calculated DOC fluxes for global rivers (Tables 1, 2), Dai et al. (2012) have subtracted $\sim 20$ Tg of DOC toward DOC removal during its transport into the Arctic.

\section{ROLE OF OCEANIA IN TERRESTRIAL OC EXPORT}

Estimations of DOC and POC fluxes from Oceania reveal large uncertainties. For instance, DOC flux based on the mean concentration of $4.76 \pm 1.60 \mathrm{mg} \mathrm{L}^{-1}$ from two rivers data in Oceania has been calculated as $2.82 \pm 0.95 \mathrm{Tg} \mathrm{C} \mathrm{yr}^{-1}$ (Dai et al., 2012) (Figure 3A and Table 2). Huang et al. (2012) calculated DOC flux for Oceania with a different water discharge as 4.48 $\mathrm{Tg} C \mathrm{yr}^{-1}$. However, NEWS model estimated around four to

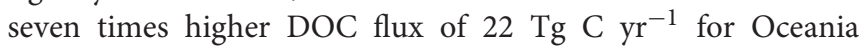
(Figure 3A), further suggesting that the sparse availability of measured DOC data may not be correctly reproducing the DOC flux for Oceania. Likewise, estimations of POC fluxes had some extreme values. The earliest study estimated POC discharge based on the carbon isotopic $\left(\delta^{13} \mathrm{C}\right)$ composition of riverine POC in Papua New Guinea and then extrapolated to entire

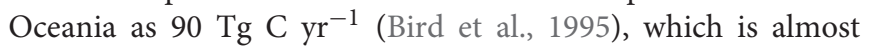
$40 \%$ higher than another estimate of $48 \mathrm{Tg} \mathrm{C} \mathrm{yr}^{-1}$ of POC by Lyons et al. (2002). To our knowledge, POC flux data of Taiwan largely comes from event-associated (typhoon) sampling and therefore most POC flux is expected to deliver directly into the deep ocean through narrow/non-existent continental shelves or through submarine canyons by short, high energy rivers (Kao et al., 2014; Selvaraj et al., 2015). Interestingly, the Taiwanese rivers are characterized by hyperpycnal mode of transport and storm-hyperpycnal delivery may contribute up to $40 \%$ of annul sediment supply, but just within $\sim 1 \%$ of time (Kao and Milliman, 2008) and therefore it is difficult to get the true picture of DOC and POC discharges for Taiwan, which in turn is probably true for the entire Oceania.

Based on the contents of TOC, $\delta^{13} \mathrm{C}$ and radiocarbon $\left(\Delta^{14} \mathrm{C}\right)$ measured in river suspended particles in Taiwan and surface and core sediment samples in the surrounding marine areas, Kao et al. (2014) calculated the burial flux of organic carbon that derived

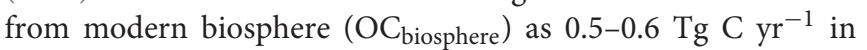
sediments derived from Taiwan with an $\mathrm{OC}_{\text {biosphere }}$ burial yield of $13-16 \mathrm{Mg} \mathrm{C} \mathrm{km}^{-2} \mathrm{yr}^{-1}$. Similarly, the rock-derived organic carbon $\left(\mathrm{OC}_{\text {petro }}\right.$, an unique characteristic of rivers draining metasedimentary rocks) that is reburied offshore Taiwan has been

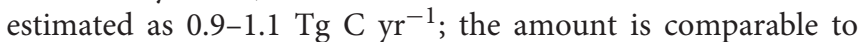
the total $\mathrm{OC}_{\text {petro }}$ buried in the Bay of Bengal annually (Galy et al., 2008). These estimates suggest that $\mathrm{OC}_{\text {biosphere }}$ burial from Taiwan may represent approximately $1 \%$ of the estimated total annual OC burial in the oceans (Schlünz and Schneider, 2000; Burdige, 2005) from just $0.02 \%$ of Earth's land surface. If this amount of terrestrial $\mathrm{OC}_{\text {biosphere }}$ content from Taiwan is recalculated based on the Oceania sediment export of $\sim 7100$ $\mathrm{Tg}_{\mathrm{yr}}{ }^{-1}$ (Milliman and Farnsworth, 2011), then the terrestrial $\mathrm{OC}_{\text {biosphere }}$ burial flux from the mountain islands of Oceania

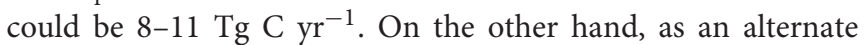
estimate, it could be presumed that the $\mathrm{OC}_{\text {biosphere }}$ burial yield from Taiwan (13-16 $\mathrm{MgC} \mathrm{km}^{-2} \mathrm{yr}^{-1}$ ) holds over the Oceania area $\left(2.7 \times 10^{6} \mathrm{~km}^{2}\right)$, giving a terrestrial $\mathrm{OC}_{\text {biosphere burial flux of }}$ 35-40 $\mathrm{TgC}_{\mathrm{yr}}{ }^{-1}$, which is closely similar to an estimate made by Lyons et al. (2002), but lower than flux rate (102.2 $\mathrm{Tg} \mathrm{C} \mathrm{yr}^{-1}$ ) recalculated in this study (Table 2 ). However, the conservative estimate of $\mathrm{OC}_{\text {biopshere }}$ burial by the erosion of Oceania estimated by Kao et al. (2014) is globally significant, as it represents about $10 \%$ of the total OC burial in clastic sediments in the oceans (Schlünz and Schneider, 2000; Burdige, 2005). 


\section{GLOBAL SOURCES AND SINKS}

In order to evaluate the significance of riverine influx of terrestrial carbon to the ocean, it is essential to distinguish how much riverine organic carbon is finally stored in marine sediments. To do this, one should differentiate the amount of riverine terrestrial OC flux and burial rate from that of the primary production and burial rates of marine OC (Schlünz and Schneider, 2000; Burdige, 2005, 2007). Here we therefore compare global sources and sinks of OC in marine sediments (Table 3 ). The distinction between terrestrial and marine $\mathrm{OC}$ can be achieved based on the stable isotopic composition of total organic carbon $\left(\delta^{13} \mathrm{C}_{\mathrm{org}}\right)$ in marine sediments (Burdige, 2005, 2007). The idea behind the use of $\delta^{13} \mathrm{C}_{\text {org }}$ for this differentiation is that both marine primary producers and nearly all land plants use the same Calvin $\mathrm{C}_{3}$ pathway of carbon fixation, which roughly leads to similar amounts of carbon fractionation during photosynthesis (e.g., Fogel and Cifuentes, 1993). However, differences in the isotopic composition between these two photosynthetic autotrophs arise from their carbon sources, mainly oceanic bicarbonate $\left(\mathrm{HCO}_{3}^{-}\right)$ for marine phytoplankton and atmospheric $\mathrm{CO}_{2}$ for land plants. With the $\delta^{13} \mathrm{C}$ value of atmospheric $\mathrm{CO}_{2}$ in the Holocene (ca. $-7 \%$ ) and the $\delta^{13} \mathrm{C}$ value of oceanic $\mathrm{HCO}_{3}^{-}$of about $0 \%$ (Degens, 1969; Galimov, 2006), land plants produce organic matter with an average $\delta^{13} \mathrm{C}$ value of $-27 \%$ (range: -25 to $-28 \%$ ) while marine phytoplankton yield $\delta^{13} \mathrm{C}$ value that average roughly $-20 \%$ for marine organic matter (e.g., Fogel and Cifuentes, 1993; Hedges et al., 1997; Meyers, 2014). Consistent to this carbon isotope systematics and isotopic ratios of major sources, studies of deltas and adjacent coastal zones often indicate sharp offshore increases in $\delta^{13} \mathrm{C}_{\text {org }}$ from values typical of land plants $(-28$ to $-25 \%$ ) to higher values similar to marine plankton ( -22 to $-18 \%$ ) (Emerson and Hedges, 1988; Meyers,
1994; Hedges et al., 1997), while sediments of continental margin fall in between these two equally dominant OC sources, but still closer to marine algal OM ( -23 to $-21 \%$ ). Carbon isotopic studies of OC in marine sediments therefore mostly revealed a dual origin with varying proportions of terrestrial- and marinederived OC in sediments of continental margins and adjoining submarine canyons and troughs (e.g., Hedges et al., 1997; Goñi et al., 1998; Burdige, 2005; Kao et al., 2014; Selvaraj et al., 2015).

Marine OM is synthesized mainly by phytoplankton, the largest ever-known marine OC source, and satellite ocean-color sensors offer a vast potential to resolve the spatial and temporal variability of marine primary production (PP) in recent years (e.g., Carr et al., 2006). From the ocean color-based models for six months of 1998 (January, March, May, July, September, and November), these authors estimated a range of global marine PP 233-71 $\mathrm{Pg} \mathrm{C} \mathrm{yr}^{-1}$ with a mean global PP of $50.7 \mathrm{Pg} \mathrm{C} \mathrm{yr}^{-1}$ (Table 3). This amount is roughly consistent with the previous estimate of the global mean PP of $55 \mathrm{Pg} \mathrm{C} \mathrm{yr}^{-1}$, which is based on the GCM-based models (Field et al., 1998). These mean global $\mathrm{PP}$ values are slightly higher than that of earlier estimates $(36.5 \mathrm{Pg}$ C $\mathrm{yr}^{-1}$ by Antoine et al. (1996); $40 \mathrm{Pg} \mathrm{C} \mathrm{yr}^{-1}$ by Liu et al. (2000)). According to Berger et al. (1989), these PP values vary between 25 and $50 \mathrm{~g} \mathrm{C} \mathrm{m}^{-2} \mathrm{yr}^{-1}$ in the centers of open-ocean subtropical gyres to $>250 \mathrm{~g} \mathrm{C} \mathrm{m}^{-2} \mathrm{yr}^{-1}$ in upwelling areas, where the surface productivity is high owing to the bottom-up supply of nutrients.

Because of its labile nature, after leaving the euphotic zone, most of the marine OC becomes rapidly recycled during its descent through the water column and only a small amount is buried in sediments. Liu et al. (2000) calculated a PP of 7.8 Pg $\mathrm{C} \mathrm{yr}^{-1}$ for the coastal ocean and if we take this amount into account, then a global marine PP for the open ocean is about 42.9 $\mathrm{Pg} \mathrm{C} \mathrm{yr}^{-1}$ (Table 3). The average burial efficiency of marine $\mathrm{OC}$ in the open ocean and coastal ocean is around 0.03 and

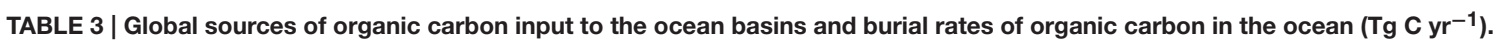

\begin{tabular}{|c|c|c|c|c|}
\hline \multirow{2}{*}{$\begin{array}{l}\text { Sources of organic carbon } \\
\text { Global marine PP }\end{array}$} & \multirow{2}{*}{$\begin{array}{c}\text { Range ( } \mathbf{T g ~ C ~} \mathbf{~ y r}^{-\mathbf{1}} \text { ) } \\
32900-70730\end{array}$} & 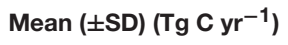 & \multirow[t]{2}{*}{ Burial \% } & \multirow[t]{2}{*}{ Burial rate $\left(\mathrm{Tg} \mathrm{C}_{\mathrm{yr}}{ }^{-1}\right)$} \\
\hline & & $50700( \pm 2000)$ & & \\
\hline Coastal ocean PP & 7800 & & 0.80 & 62.4 \\
\hline Open ocean PP & 42900 & & 0.03 & 12.9 \\
\hline River input (DOC) & $170-250$ & $212( \pm 29)$ & - & - \\
\hline River input (POC) & $150-276$ & $203( \pm 41)$ & - & - \\
\hline \multicolumn{2}{|l|}{ Total } & & & 165.3 \\
\hline \multicolumn{2}{|l|}{ Burial rate of organic carbon } & \multicolumn{2}{|c|}{ Total OM burial rate } & TOM burial rate \\
\hline \multicolumn{2}{|l|}{ Deltaic sediments } & \multicolumn{2}{|l|}{70} & $47( \pm 17)$ \\
\hline
\end{tabular}

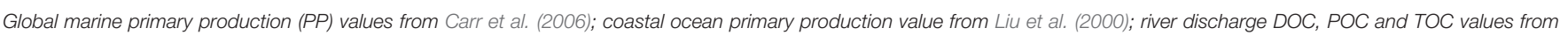

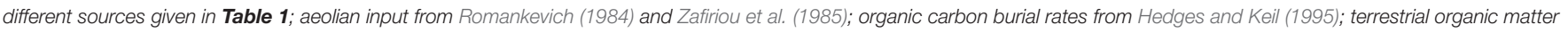
(TOM) burial rates from Burdige (2005). 
0.8\%, respectively (Berger et al., 1989). While taking these PP values and burial efficiencies for the coastal and open ocean into account, then it turns out that annual marine OC burial rate of about $0.062 \mathrm{PgC} \mathrm{yr}^{-1}$ and $0.013 \mathrm{PgC} \mathrm{yr}^{-1}$, respectively (Table 3). These burial rates are consistent with the previous estimates (0.055 and 0.009 Pg) of Schlünz and Schneider (2000), though they have adopted slightly lower PP values for global (36.5 Pg C $\mathrm{yr}^{-1}$ ), coastal (6.9 $\mathrm{Pg} \mathrm{C} \mathrm{yr}^{-1}$ ) and open ocean (29.6 $\mathrm{Pg} \mathrm{C} \mathrm{yr}^{-1}$ ) breakouts.

Berner (1982) estimated global OC accumulated in deltaicshelf sediments to be $126 \mathrm{Tg} \mathrm{C} \mathrm{yr}^{-1}$ and based on the global rate of sediment discharge from rivers multiplied with average OC content of deltaic-shelf sediments, Berner further subdivided

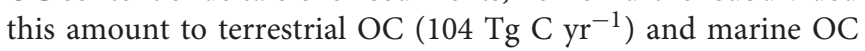

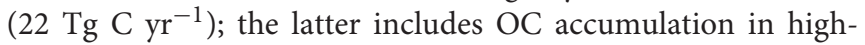
productivity regions $\left(10 \mathrm{Tg} \mathrm{C} \mathrm{yr}^{-1}\right)$, shallow water carbonaterich sediments $\left(6 \mathrm{Tg} \mathrm{C} \mathrm{yr}^{-1}\right)$, pelagic sediments $\left(5 \mathrm{Tg} \mathrm{C} \mathrm{yr}^{-1}\right.$ ) and in anoxic basins ( $1 \mathrm{Tg} \mathrm{C} \mathrm{yr}^{-1}$ ). Later Hedges and Keil (1995) recalculated Berner's estimate assuming that $33 \%$ of the riverine load is deposited outside of deltas, with twice the average OC content of deltaic sediments. Accordingly, this estimate amounts in a burial of $70 \mathrm{Tg} \mathrm{C} \mathrm{yr}^{-1}$ in deltaic sediments and $68 \mathrm{Tg} \mathrm{C} \mathrm{yr}^{-1}$ in shelf sediments (Table 3). Since the total OC content has been applied in these two studies to estimate terrestrial OC, it has been criticized that these studies must have overestimated terrestrial $\mathrm{OC}$, as both depositional systems can also accumulate marine OC (Schlünz and Schneider, 2000). To overcome this complication, Burdige (2005) used carbon isotope ratios in deltaic and nondeltaic continental margin sediments to calculate terrestrial organic matter (TOM) burial rate. First, he calculated the burial efficiency (i.e., the burial rate of OM at depth in sediments where remineralization is inactive divided by the OM input rate) of TOM in marine sediments and then combined with estimates of total carbon burial in marine sediments from Hedges and Keil (1995) to estimate the burial rate of TOM (see original references for the detailed assumptions of calculation). Accordingly, the estimated rate of TOM in deltaic sediments is $47 \pm 17 \mathrm{Tg} \mathrm{C}$ $\mathrm{yr}^{-1}$ and in non-deltaic continental margin sediments is $11 \pm$ $3 \mathrm{Tg} \mathrm{C} \mathrm{yr}^{-1}$ (Table 3). For all continental marginal sediments, this rate is $58 \pm 17 \mathrm{Tg} \mathrm{C} \mathrm{yr}^{-1}$, indicating that the burial of TOM is dominated by deltaic sediments and TOM burial seems to be almost insignificant in other sedimentary depositional realms (Burdige, 2005). Overall, these rates imply that roughly one third of the organic carbon ( $44 \pm 13 \%$ of total $\mathrm{OM})$ buried in marine sediments is of terrestrial in origin (Burdige, 2005). Adding this newly estimated TOM burial rate along with the burial rate of $32 \mathrm{Tg} \mathrm{C} \mathrm{yr}{ }^{-1}$ for aeolian input (similar to the one adopted by Schlünz and Schneider, 2000), then the global burial of OC in marine sediments amounts to $\sim 165 \mathrm{Tg} \mathrm{C} \mathrm{yr}^{-1}$ (Table 3). Even though our new estimate using updated marine and TOM burial rates are slightly higher than the estimates of Berner (1982) and Schlünz and Schneider (2000), our revised rate is consistent with the previous estimate of Hedges and Keil (1995) (Table 3) as

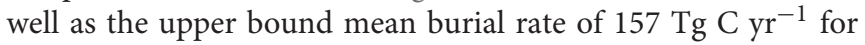
whole-ocean sediments calculated earlier (Wollast, 1991).

\section{CARBON BURIAL IN THE MARINE ENVIRONMENT}

The burial of OC in marine sediments is a major process affecting the amount of carbon storage in the ocean-atmosphere pool, and therefore drives the oxygenation of the atmosphere on geological time scales. Therefore, to further understand the burial of OC in marine sediments, we compiled data of marine $\mathrm{PP}$, rain rate, remineralization rate, burial rate (Muller-Karger et al., 2005), POC export (Dunne et al., 2007) and burial efficiency (Burdige, 2007) for all marine sediments, continental margin and deep-sea sediments (Table 4). Details of these calculations are available in the above mentioned original references and therefore we have not elaborated here. However, most estimates collated in Table 4 are from Muller-Karger et al. (2005), Burdige (2007), and Dunne et al. (2007). For instance, Muller-Karger et al. (2005) used satellite data of 1998-2001 to estimate net primary production, which was attenuated with water column depth using standard empirical models. This was then applied to global bathymetry database to determine $\mathrm{OC}$ rain rates to continental margin and deep-sea sediments. Using assumed burial efficiency (based on those in Figure 2 of Burdige, 2007), OC burial rates and remineralization rates were estimated. On the other hand, Dunne et al. (2007) applied a series of algorithms starting with satellite-based PP and continuing with conversion of PP to sinking particle flux, penetration of particle flux to the deep sea, and accumulation in sediments.

From the perspective of carbon burial in the marine realm, marine PP (47,910 Tg C $\mathrm{yr}^{-1}$; Muller-Karger et al., 2005; Table 4) is accounted as an overwhelmingly major OC source. This is because marine $\mathrm{PP}$ is approximately 60 times larger than the

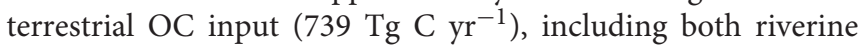
TOC (419 $\mathrm{Tg} \mathrm{yr}^{-1}$ ) and aeolian flux of OC (320 $\mathrm{Tg}^{-1}$ )

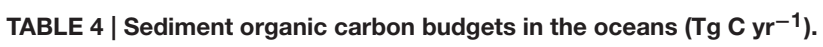

\begin{tabular}{|c|c|c|c|c|c|c|}
\hline & $\begin{array}{l}\text { Marine PP } \\
\left(\operatorname{Tg~C~yr}^{-1}\right)\end{array}$ & $\begin{array}{l}\text { POC export } \\
\left(\mathrm{Tg} C \mathrm{yr}^{-1}\right)\end{array}$ & 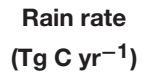 & 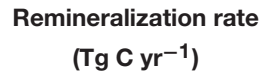 & 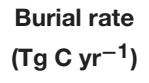 & $\begin{array}{c}\text { Burial } \\
\text { efficiency (\%) }\end{array}$ \\
\hline All marine sediments & 47910 & $9600( \pm 3600)$ & 930 & 775 & 155 & 16.7 \\
\hline Deep-sea/open ocean & 38920 & $7798( \pm 2924)$ & 310 & 217 & 93 & 30.0 \\
\hline
\end{tabular}

Global marine primary production (PP) values from Muller-Karger et al. (2005); POC export from Dunne et al. (2007); rain rate, remineralization rate, burial rate and burial efficiency from Muller-Karger et al. (2005). The burial efficiency is the rate of OC burial divided by rain rate to the sea floor, as discussed in Burdige (2007). 
(Table 3). Among the substantial marine OM synthesizing in the brighter surface ocean, $\sim 80 \%$ is remineralized within the euphotic zone and $\sim 5 \%$ (2629 $\mathrm{Tg} \mathrm{C} \mathrm{yr}^{-1}$, Burdige, 2007; 2300 $\mathrm{Tg} \mathrm{C} \mathrm{yr}^{-1}$, Dunne et al., 2007) could escape remineralization or oxidation, reaching the bottom of water column as marine rain (Table 4). Nonetheless, only less than $0.5 \%\left(\sim 155 \mathrm{Tg} \mathrm{yr}^{-1}\right.$; Burdige, 2005, 2007) of OC in surface water or $\sim 17 \%$ of rain rate buried ultimately in the sea floor is normally incorporated into carbon cycle on a longer geologic time scale (Burdige, 2007; Blair and Aller, 2012). Marine OC is also a major component of total OC buried in global ocean sediments, with a proportion of $64 \%$ (Burdige, 2005), mainly due to the predominance of marine PP input. This significant occupation of marine OC seems not to be consistent with its reactive nature. However, the preservation efficiency of marine OC (i.e., the ratio of marine OC buried to that of marine PP OC input; Table 4$)$ is only $0.21 \%(0.25-1.3 \%$; Burdige, 2007), more than an order of magnitude lower than that of $7.7 \%$ for terrestrial OC (9-17\%; Burdige, 2007). Therefore, from this perspective, marine $\mathrm{OC}$ is more efficiently decomposed than terrestrial OC. Table 4 shows that, although POC export is lower for continental margin than deep-sea sediments, higher rain and remineralization rates facilitate lower burial rate in continental margin than in the deep-sea. Burdige (2007) noted that $\mathrm{OC}$ remineralization rates and $\mathrm{OC}$ rain rates for either whole ocean, continental margin, or deep-sea sediments vary by only a factor of $\sim 4-5$ and $\sim 3-8$, respectively. In contrast to these two rates, OC burial rates in marine sediments vary by more than an order of magnitude among the different budget calculations,

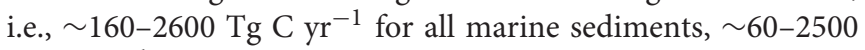
$\mathrm{Tg} \mathrm{C} \mathrm{yr}^{-1}$ for continental margin sediments, and $\sim 2-300 \mathrm{Tg}$ $\mathrm{C} \mathrm{yr}^{-1}$ for deep-sea sediments (refer to Table 3 in Burdige, 2007). Furthermore, these burial rates are significantly higher than conventionally referred whole ocean OC burial rates of 120-160 Tg C yr $^{-1}$ (Berner, 1989; Hedges and Keil, 1995; see also Table 3). Although several reasons might be responsible for such discrepancies among these rates, attempting to explain them is beyond the scope of this work.

Dunne et al. (2007) also estimated that $12 \%$ of the PP $(6.5 \pm$ $\left.0.7 \mathrm{Pg} \mathrm{C} \mathrm{yr}^{-1}\right), 21 \%$ of the particle export $\left(2.0 \pm 0.7 \mathrm{Pg} \mathrm{C} \mathrm{yr}^{-1}\right)$, $71 \%$ of the flux to sediments $\left(1.6 \pm 0.6 \mathrm{Pg} \mathrm{C} \mathrm{yr}^{-1}\right)$ and $85 \%$ of the total burial flux $\left(0.67 \pm 0.45 \mathrm{Pg} \mathrm{C} \mathrm{yr}^{-1}\right)$ occur on the shelves with less than $200 \mathrm{~m}$ water depths. On the other hand, continental slope regions of $200-2000 \mathrm{~m}$ (only $7 \%$ of the open ocean area), accounts for $53 \%$ of the open ocean POC flux to sediments, but it responsible for $89 \%$ of open ocean organic carbon burial. Although this region is responsible for $69 \%$ of particle export out of the surface ocean PP, it has been suggested that interior recycling of organic carbon allows only $2 \%$ of global sediment burial (Dunne et al., 2007). Dunne et al. (2007) estimated global organic carbon burial of $0.79 \mathrm{Pg} \mathrm{C} \mathrm{yr}^{-1}$, which is higher than the previous estimate of $0.22 \mathrm{Pg} \mathrm{C} \mathrm{yr}^{-1}$ by Muller-Karger et al. (2005), as the former study included nearshore regions (0-50 m)

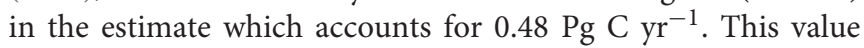
is almost two times higher than the global OC burial estimate of 0.12-0.25 $\mathrm{Pg} \mathrm{C} \mathrm{yr}^{-1}$ the rate that has helped to conceive the geochemical conundrum of "missing organic carbon" (Hedges and Keil, 1995; Hedges et al., 1997). Nevertheless, the estimate of Dunne et al. (2007) is consistent with the estimation of carbon sequestration at the top of permanent thermocline, i.e., $0.77 \mathrm{Pg} \mathrm{C}$ and also closely fall in the upper end of carbon sequestration at $2000 \mathrm{~m}$ (Guidi et al., 2015).

\section{TERRESTRIAL OC BURIAL ON GLACIAL-INTERGLACIAL TIME SCALES}

Over geological time, the burial of organic matter in marine sediments controls atmospheric concentrations of gases such as $\mathrm{CO}_{2}, \mathrm{O}_{2}$ and $\mathrm{CH}_{4}$, regulating the Earth's climate on glacialinterglacial time scales. Assuming a river POC discharge of 150-270 $\mathrm{Tg} \mathrm{C} \mathrm{yr}^{-1}$ (mean: $203 \pm 41 \mathrm{Tg} \mathrm{C} \mathrm{yr}^{-1}$ ) and TOM burial rate of $\sim 40-85 \mathrm{Tg} \mathrm{C} \mathrm{yr}^{-1}$ (Table 3), it is evident that $\sim 110-185 \mathrm{Tg} \mathrm{C} \mathrm{yr}^{-1}$ of terrestrial OC is remineralized annually. This remineralized amount is analogous to the present-day rate of total carbon burial in all marine sediments $(\sim 160 \mathrm{Tg} \mathrm{C}$ $\mathrm{yr}^{-1}$; Tables 3, 4). By comparing the modern and Last Glacial terrestrial $\mathrm{OC}$ discharge, accumulation and burial rates from the Amazon River-continental margin-Amazon Fan continuum (Schlünz et al., 1999; Schlünz and Schneider, 2000), it has been suggested that there was no significant difference of terrestrial OC burial between these two climate states, but the depocenters for land-derived materials thought to be shifted from the shelf to deep sea fan due to low sea level. However, quantification of natural variations in the burial of OC in deep sea sediments over the last glacial cycle by compiling hundreds of sediment cores indicated $\sim 50 \%$ higher OC accumulation rate in the deep sea during glacial maxima than during interglacial intervals over the past $150 \mathrm{kyr}$ (Cartapanis et al., 2016). Figure 4 shows that the global mass accumulation rate of TOC (TOC MAR) during the Last Glacial Maximum (LGM) was $\sim 118-171 \%$ of the Holocene MAR, with a mean estimate of $147 \pm 18 \%$. Similar amplitude of TOC MAR was also evident in marine isotope stage 6 (MIS 6), wherein the burial was $\sim 148-183 \%$ of interglacial MIS 5e (Figure 4). Based on this study, Cartapanis et al. (2016) estimated that the glacial excess TOC burial in the deep sea might have removed about 200-500 Pg C from the ocean-atmosphere system. Earlier, Mollenhauer et al. (2004) also found a 2-3-fold increased OC accumulation during the LGM compared to midHolocene interval in the South Atlantic sediment cores. These reconstructions of global OC burial suggested an increased burial during glacial maxima due to a combination of more rapid export of OM from the surface mixed layer, more efficient transfer of OM from the upper ocean and continental margins to the seafloor, and better preservation of OM in the sediment.

During low sea level glacial times, the absence of significant continental shelves can facilitate the transfer of both marine and terrestrial $\mathrm{OM}$ from the coastal zone to the deep sea through downslope transport and nepheloid layers and therefore bypassing temporary storage and partial remineralization on shelves, and increasing burial efficiencies (e.g., Keil et al., 1997). Consistent to this suggestion, enhanced preservation of terrestrial OC has been noted in sediments accumulated in glacial periods in the Amazon Fan (Goñi et al., 1997; Keil et al., 1997), and in the Mississippi Cone in the Gulf of Mexico (Newman et al., 1973). 


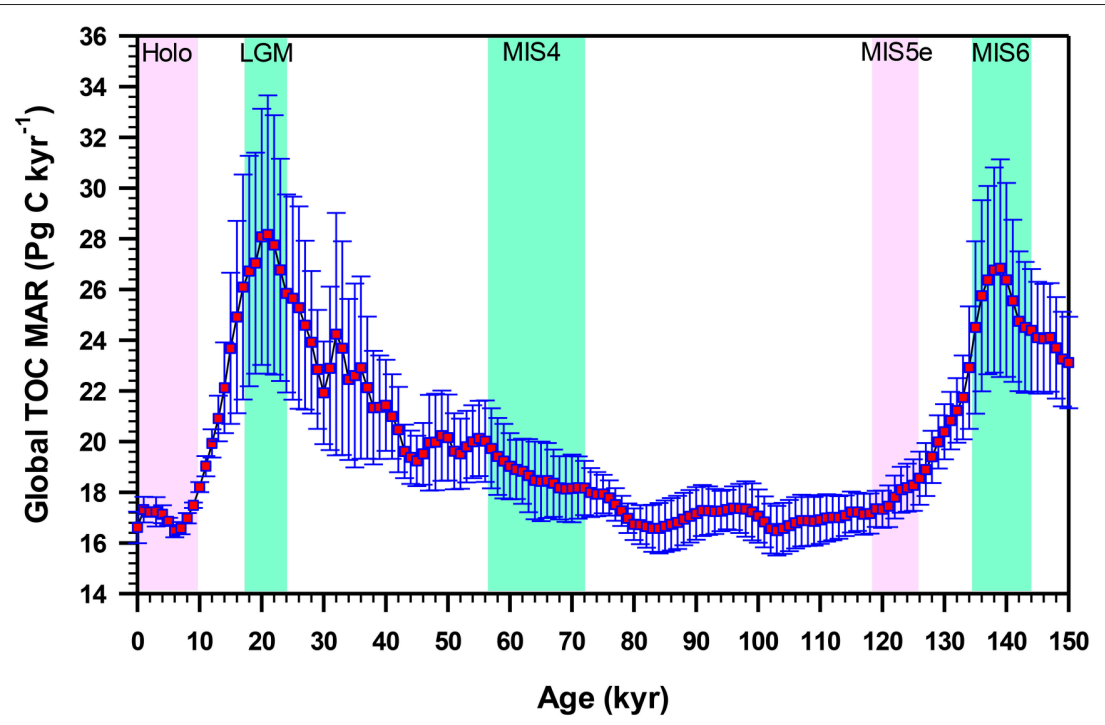

FIGURE 4 | Reconstructed global mean (with standard deviation) mass accumulation rate of total organic carbon (TOC MAR) in deep sea sediments showing higher TOC MAR during glacial intervals compared to interglacial periods (Redrawn from Cartapanis et al., 2016). Pink vertical bars correspond to interglacial periods (Holocene and Marine Isotope Stage (MIS) 5e; light green vertical bars correspond to glacial intervals (Last Glacial Maximum (LGM), MIS 4, and MIS 6.

Indeed, terrestrial organic carbon deposited at the mouth of the Amazon River under present-day conditions was transferred almost entirely to the deep-sea fan during the LGM (Schlünz et al., 1999). Given these mechanisms in favor of the glacial burial pulses of organic carbon and their correspondence with sea level and global ice volume (Figure 2 in Cartapanis et al., 2016), it is clear that deep-sea organic carbon burial is very sensitive to climate. The excess burial of 200-500 Pg C of OC in deep-sea sediment during glacial intervals found to be analogous to the excess carbon stored in land under ice sheets, soil, permafrost and peat deposits during glacial intervals (Zeng, 2003; Ciais et al., 2012). Furthermore, the fact that single major deep-sea fan off the Amazon basin accounts for a significant part of glacial OM burial points to the need for studies specifically targeting deep-sea fans, submarine canyons, slopes and troughs for "missing terrigenous carbon," though enhanced carbon burial sites are favorable places of new export production fueled by dust inputs during glacial intervals rather than shelf or slope sediments (Mollenhauer et al., 2004; Cartapanis et al., 2016).

The aforementioned terrestrial OC export and burial along the land-deep sea continuum signify that the well-known caveat in the scientific understanding of the natural carbon cycle is the "missing terrigenous carbon" in the sediments of continental margin. Based on stable carbon isotope and lignin distributions, it is believed that most of the land-derived OM discharged by rivers to the ocean is deposited in near shore regions (e.g., Gearing et al., 1977; Hedges and Mann, 1979). On the other hand, carbon isotope (Druffel et al., 1986) and lipid biomarker studies (Zafiriou et al., 1985; Prahl and Muehlhausen, 1989) indicated the presence of appreciable amounts of terrigenous $\mathrm{OM}$ in the water column and sediments at open ocean sites. Studying export processes of terrigenous OM to offshore and open ocean regions, including submarine canyons, fjord, deep sea environments, is thought to provide some solutions for the "missing" carbon issue (Tesi et al., 2014; Selvaraj et al., 2015; Smith et al., 2015). It seems that such studies will not completely solve the problem, though results of these studies provide additional insights on the mechanism of OC transport to deeper parts of the ocean. Major uncertainties therefore still remain unchanged in our understanding of the natural, undisturbed carbon cycle of the coastal and open oceans that requires elucidation of remineralization processes and/or revising the budgets aided with more observational and analytical data and model simulations.

As aptly put by Eglinton and Repeta (2014), "in most cases our understanding of $\mathrm{OM}$ in the contemporary ocean remains far from complete." These areas are (i) the fate of terrigenous organic carbon inputs in the ocean, (ii) the compositions of oceanic dissolved organic matter (DOM), (iii) the mechanisms of OC preservation, and (iv) new insights into microbial inputs and processes. To better constrain the global $\mathrm{C}$ cycle in terms of sources and sinks and to distinguish natural from anthropogenic inputs of carbon in the marine environment, intensive research efforts are the need of the hour. Such studies should utilize the modern state-of-the art instrumental facilities, newly introduced observational systems and applications of sophisticated models on the biogeochemical cycles of $\mathrm{C}$ and other nutrients ( $, \mathrm{P}, \mathrm{S}$, and $\mathrm{Fe}$ ) in the land-deep sea continuum. In addition to these general key issues in marine biogeochemistry, here we focus the following four lines/ways of investigations that we deem would provide required data to refine/revise the terrestrial carbon export/marine burial budget and therefore to bridge the gap in our understanding of the global C cycle. 


\section{EXTREME PRECIPITATION IN CARBON EXPORT}

Event-based (e.g., precipitation) fluxes of terrestrial DOC and POC in rivers are important in diverse ecosystems, including forested watersheds (Raymond and Saiers, 2010) and densely vegetated mountainous islands (Goldsmith et al., 2008; Hilton et al., 2008). This is mainly because $\sim 70 \%$ of event-based DOC and POC fluxes occur during the rising hydrograph and during large rainfall events. Not only the composition of particulate OM carried by major rivers vary seasonally with the hydrograph, but also the quantity, source and degradation state of terrestrial $\mathrm{OM}$ are dramatically altered under flooding conditions (Ittekkot and Arain, 1986; Dalzell et al., 2005). For example, the relative concentrations of major biochemicals, such as amino acids and sugars, are highest during periods of low sediment discharge, whereas biodegraded organic substances predominate at high discharge (Ittekkot et al., 1985; Ittekkot and Arain, 1986). Numerous studies now support precipitation as a dominant effect on these fluxes in the coming decades (Raymond and $\mathrm{Oh}$, 2007; Godsey et al., 2009). Furthermore, rapid river transport times associated with large hydrological events will result in the bypassing of terrestrial carbon processing in rivers, which will have an impact on $\mathrm{CO}_{2}$ sequestration, and concomitant episodic disturbances to coastal carbon budgets (Bianchi et al., 2013) and lead to shift in the timing of terrestrial carbon delivery to the coastal ocean under future climate change scenarios.

In addition to annual precipitation and temperature, it is now clear that hydrologic events such as extreme rainfall from tropical storms are disproportionately important to riverine sediment and organic carbon transport (Bianchi et al., 2013; Selvaraj et al., 2015). The erosive power of these storms is responsible for most POC export from watersheds to the coastal ocean, especially in mountainous regions where short rivers are traversing (Hilton et al., 2008). Increases in riverine DOC concentrations and hence in annual riverine DOC export to coastal systems can also result from these events. For example, a single tropical storm can be responsible for more than $40 \%$ of average annual riverine DOC export (Yoon and Raymond, 2012). On decadal time scales, single large flood events can export $80-90 \%$ of POC from mountainous regions (Hilton et al., 2008).

\section{ORGANIC-INORGANIC LINK}

Even though OC and mineral breakdown are spatially separated in the Earth's Critical Zone, studies of OC turnover in soils and sediments have started to discuss the mechanisms for the coupling of mineral and biogeochemical cycles via organicmineral interactions, which prevent the oxidation of OM by stabilizing humic substances in soil and sedimentary systems (e.g., Hedges and Keil, 1995; Keil and Mayer, 2014). Sorption processes play an important role in transforming labile DOM into stable soil OM (Guggenberger and Kaiser, 2003). Substrates may also slow the process of carbon remineralization if they are adsorbed onto particles (e.g., clays) or form complexes with macromolecules (e.g., humic substances) (Mayer et al., 2004; Burdige, 2007; Arnosti, 2011). The smectite-bearing shelf sediments derived from Deccan Trap shown to contain enriched carbon isotope values, even richer than marine organic matter (Kurian et al., 2013). It is also known that most OC is rapidly metabolized and/or photolysed and returned to the atmosphere as $\mathrm{CO}_{2}$ (Cole et al., 2007), when they are not adsorbed onto mineral particles. Selective degradation over the residence time of the estuarine and river systems may leave more recalcitrant material OM, resulting in pre-aging material before reaching the oceans (Raymond and Bauer, 2001). Therefore, the rate of erosion, delivery, and mixing of fresh mineral surfaces with fresh OM could likely control watershed to global-scale C sequestration fluxes over both current and geological time scales (Hedges, 1992; Kennedy and Wagner, 2010).

However, a number of studies have evaluated the organicinorganic link separately with less attention paid to assess the mineral adsorption and the significance of organic-inorganic interaction. This organic-mineral interaction provides a clue to the missing carbon mystery, as $90 \%$ of the OC burial in the ocean occurs in estuarine, lagoonal, deltaic and margin sediments and is associated with mineral particles largely of mud size (Hedges and Keil, 1995; Cowie et al., 2014). This terrigenous OC associated with minerals seems to be exchanged with marine OM once it enters the coastal ocean (Nuwer and Keil, 2005; Selvaraj et al., 2015); one of the potential reasons why we do not see as much terrigenous carbon as expected from riverine inputs (Bianchi, 2011). As mentioned in Keil and Mayer (2014), "despite more than 100 years of research, we are still only scratching the surface of understanding regarding the ways in which organic matter and minerals interact in the natural world."

Oceanic islands in the tropical and subtropical regions, especially those located in the Pacific and Indian Oceans (e.g., Taiwan, the Philippines, Indonesia, Sri Lanka, etc.) have rarely been investigated for their roles on sediment and nutrients export both in the normal season and during extreme (tropical storm) events. These islands with their diverse lithology and mineral dissolution rates can produce characteristics clay minerals through physical erosion and chemical weathering and may provide an unknown link between mineral and organic matter export and burial in the regional marine depositional center, but yet to be investigated in detail. Notably, almost there is no information on quality and quantity of terrestrial OM export from the Philippines and Sri Lanka, two islands often smashed by tropical storms in the low-latitude region. Therefore, such climatically-vulnerable areas should be focused to understand the influence of erosion on the global carbon cycle and organicinorganic interactions.

\section{BIOGEOCHEMISTRY OF HADAL WORLD}

The largest carbon pool resides in the intermediate and deep ocean (ca. 37,100 Pg C; Figure 1), which includes the hadal ecosystem; the largest living but dark space on Earth. Nonetheless and importantly, $\mathrm{C}$ (and $\mathrm{N}$ ) dynamics in this dark world remain completely elusive. Until today, relatively little is heard about the biogeochemistry of hadal trenches (e.g., Glud et al., 2013; Nunoura et al., 2015). These studies believed that patterns of food supply in hadal environments are affected by the 
physical topography, as the steep slope of trenches facilitate a downward transport and subsequent accumulation of POC along the trench axis, making the supply of nutrients to trench systems fundamentally distinct to that on the flat neighboring abyssal ecosystems. Furthermore, compared to abyssal plains, a faster attenuation of oxygen $\left(\mathrm{O}_{2}\right)$ concentration and high rates of microbial $\mathrm{C}$ turnover in sediments have been noted at Challenger Deep due to an intensified $\mathrm{O}_{2}$ consumption within trench sediments (Glud et al., 2013). Since the hadal microbial ecosystem is distinct and driven by the endogenous recycling of OM (Nunoura et al., 2015), tracking the pulsed sources of $\mathrm{OM}$ to these ecosystems would provide new insights into the biogeochemical cycles of $\mathrm{C}$ and $\mathrm{N}$ and other nutrient-like elements.

Until today, much of the research on microbial ecology and biogeochemistry has been done on the sunlit layer of the upper ocean water column $(<200 \mathrm{~m})$. Nonetheless, the dark ocean characterized by the absence of light, high pressure, low temperature, and elevated inorganic nutrient concentrations is less focused, though it contains around 98\% of the ocean's dissolved inorganic carbon (Gruber et al., 2004) and a significant fraction of the ocean's prokaryotic biomass (Whitman et al., 1998). The estimates of metabolic activity in the dark ocean seem to have exceeded the influx of organic materials. This is either because of the existence of unaccounted sources of organic carbon and/or that metabolic activity in the dark ocean is likely overestimated due to sampling constraints. In addition, most hadal trenches are located in close proximity to a productive coastal-open ocean interface. The lateral transport and turbidities are regarded as two most important ways of pulses of sediment and elemental transport to hadal zones, leading to substantial deposition of organic matter in trenches. Hadal trenches are important ecosystems of deep sea environments of the Pacific linked to the "Ring of Fire." Among the 37 deep-sea tranches in the world, 9 deepest are located in the Pacific (Jamieson et al., 2010). Interestingly, the western Pacific receives the largest effect of tropical storms due to an average of $\sim 20$ typhoons per year and also acts as a hot spot for global sediment production due to a combined climate-tectonic effect (Milliman and Syvitski, 1992; Milliman and Farnsworth, 2011). Hence, studies of biogeochemical cycles in hadal settings in the world ocean in general and in the western Pacific in particular would be ideal for tracking carbon transport to the darker oceanic world and associated biogeochemical transformations laterally along the land-deep sea continuum.

Though the abyssal plain sediments are known to be poor in organic carbon, sparse benthic population feeding on sediments seems to depend on food reaching in pulses. The seasonality of fluxes and episodes of higher organic matter supply seems to be major sources. There is hardly any estimate or seasonal changes in supply for the deep-abyssal areas. Sediment traps provide the only source of in situ data on deep POC flux (Henson et al., 2012). Settling flux information with season/time through the installation of sediment traps may help and certainly bring new insights into biogeochemical cycles of $\mathrm{C}$ both in dissolved and particulate forms. Therefore, systematic $\delta^{13} \mathrm{C}$ and $\delta^{15} \mathrm{~N}$ investigations in hadal environments may shed some lights about whether the dark ocean is an environment of substantial terrestrial $\mathrm{C}$ pool or not. In addition, radiocarbon $\left({ }^{14} \mathrm{C}\right)$ measurements of particles and sediments in hadal trenches, similar to studies made from other river and marine realms (Bauer et al., 1992; Raymond and Bauer, 2001; Goñi et al., 2013), may provide additional constraints on age, fate and reactivity of OM and therefore provide clues about the transport mechanism and the nature of particles and sediments in the dark ocean.

\section{IMPORTANCE OF ADDITIONAL PROXIES AND THEIR COMBINATIONS}

Since their inception, mass spectrometers are being used to measure stable isotopes for the investigation of biogeochemical cycles in terrestrial and marine ecosystems. Researchers have frequently employed $\delta^{13} \mathrm{C}$ to disentangle the global carbon cycle, though contemporary cycles of other elements such as $\mathrm{N}, \mathrm{P}$, and $\mathrm{S}$ have rarely been investigated in combination. For instance, the biogeochemical cycles of nitrogen and carbon are intimately coupled with each other due to their metabolic needs of organisms. Changes in the availability of one element will influence not only biological productivity but also availability of requirements for the other element (Gruber and Galloway, 2008). Nitrogen exists as two stable isotopes in nature: ${ }^{14} \mathrm{~N}(99.63 \%)$ and ${ }^{15} \mathrm{~N}(0.37 \%)$. The $\mathrm{N}$ cycle in marine environments consists of several exchange processes among biota, water and sediments (e.g., Altabet, 2005). The numerous oxidation states of inorganic nitrogen $(-4,0,2,3,5)$ and the multiplicity of biological pathways interconnecting different pools often make it difficult to identify clearly the key processes controlling nitrogen through ecosystems, conferring to the whole cycle greater complexity than other bio-elemental cycles, in particular the carbon cycle. Despite this complexity, the ${ }^{15} \mathrm{~N} /{ }^{14} \mathrm{~N}$ ratio in sedimentary organic matter has been widely used to investigate relative nutrient $\left(\mathrm{NO}_{3}^{-}\right)$ utilization in the overlying water column (Francois et al., 1992; Altabet and Francois, 1994; Farrell et al., 1995). Wada and Hattori (1991) demonstrated that $\delta^{15} \mathrm{~N}$ value of POM depends on the isotopic composition of the nitrogenous substrate and isotope fractionation during nitrogen uptake by marine primary producers. In the euphotic zone, the preferential uptake of ${ }^{14} \mathrm{NO}_{3}^{-}$by phytoplankton produces biosynthate enriched in ${ }^{14} \mathrm{~N}$, leaving the residual dissolved $\mathrm{NO}_{3}^{-}$progressively enriched in ${ }^{15} \mathrm{~N}$ (Schubert and Calvert, 2001; Altabet, 2005). Under nutrient-replete conditions (physical supply of $\mathrm{NO}_{3}^{-}>$biological assimilation), the settling organic detritus is depleted in ${ }^{15} \mathrm{~N}$ and thus low $\delta^{15} \mathrm{~N}$. In the eastern equatorial Pacific and the Arabian Sea, where upwelling brings subsurface nutrients to the surface at concentrations in excess of $5 \mu \mathrm{M}$ (Peña et al., 1994), bottom sediment $\delta^{15} \mathrm{~N}$ values are 5-6\%, and they increase to the north and south because of isotopic enrichment under low nutrient conditions (Farrell et al., 1995). This simple relationship can be complicated in regions of significant denitrification, which leaves subsurface waters highly enriched in ${ }^{15} \mathrm{~N}$ (>6\%; Liu and Kaplan, 1989), and in areas where atmospheric $\mathrm{N}$ fixation is important, which produces organic matter highly depleted in the heavy 
isotope $(-2 \%$ oto $+1 \%$ ) (Wada and Hattori, 1976). The latter process also causes a low $\delta^{15} \mathrm{~N}$ value in soil organic matter.

A recent multi-proxy study showed that $\delta^{13} \mathrm{C}$ composition of terrestrial particles is conserved, while the $\delta^{15} \mathrm{~N}$ composition has been altered due to admixing of marine bacteria during the transport of river-derived particles to deep-sea $(\sim 3000 \mathrm{~m}$ water depths) within a week of transit during an extreme weather condition (Selvaraj et al., 2015). Likewise, another study demonstrated the need to consider multiple terrigenous OC proxies at isotope/molecular levels to differentiate the fate for different allochthonous components in Arctic sediments (Tesi et al., 2014). Since the terrigenous OC is made of several allochthonous pools each with distinct reactivity toward the oxidation, age and carbon loading (Goñi et al., 2014; Tesi et al., 2014), application of just $\delta^{13} \mathrm{C}$ composition may perhaps be inadequate to understand the characteristics of $\mathrm{OM}$ along the river-estuary-shelf-deep sea continuum. Toward this understanding, recent studies have explored the possibilities of applying some alternate proxies to investigate OM dynamics in terrestrial and marine environments (Leri et al., 2010, 2014, 2015; Leri and Myneni, 2012). These proxies include halogens such as bromine $(\mathrm{Br})$, chlorine $(\mathrm{Cl})$ and iodine $(\mathrm{I})$ and their relationships with organic carbon and their biological transformation in marine sediments. These studies further demonstrated that $\mathrm{Br}$, $\mathrm{Cl}$ and I are mostly associated with organic carbon and marine organics are relatively enriched by these halogens compared to terrestrial organics (Mayer et al., 1981, 2007). As marine $\mathrm{OM}$ is protein-rich and thus enriched in ${ }^{15} \mathrm{~N}$ compared to ${ }^{14} \mathrm{~N}$, future studies focusing on the relationship among $\delta^{15} \mathrm{~N}$ and halogens and their ratios with organic carbon may provide additional insights of $\mathrm{OM}$ sources and its biogeochemical changes in diverse environments, including abyssal and hadal ecosystems.

Exploration of geochemistry of halogens and their biological links with $\mathrm{OM}$ is therefore essential to bring new frontiers in global elemental cycles. Furthermore, geochemical parameters such as $\mathrm{Br}, \delta^{13} \mathrm{C}, \delta^{15} \mathrm{~N}$, biogenic silica and other productivity indicators such as $\mathrm{Ba}$ and redox indicators such as Mo play a key role in distinguishing provenance of sedimentary organic matter in suspended particles and sediments in the marginal seas and open oceans; however, the potential usage of this combination, i.e., what is the relationship between and among these productivity and redox proxies and their roles in global $\mathrm{C}$ and $\mathrm{N}$ cycles, has not been explored in detail. Furthermore, a link between/among these parameters and clay mineral composition has also not been explored. Establishing halogen-organic matter link and see whether halogens have any tight link with other classical marine productivity indicators and specific terrestrial and marine environmental biomarkers will be another interesting line of research. Apart from that linking elemental ratios with terrigenous vs. marine organic matter/fraction calculated based on $\mathrm{Br} / \mathrm{OC}$ ratios to see how inorganic elements (based on XRF results) play roles in differential burial of these two forms of carbon and nitrogen would be useful to refine uncertainties associated with terrestrial carbon in source-to-sink and also can provide new information on the role of halogens in marine biogeochemical cycles.

\section{FINAL THOUGHTS}

In this review, we revisited the global riverine organic carbon fluxes and compared the recently estimated data-based fluxes with that of model-based estimation. Our comparison reveals large uncertainties in terms of terrestrial carbon export and subsequent burial in marine sediments. This confirms that additional biogeochemical studies are required for global hotspots of sediment and terrestrial carbon discharges such as Arctic and Oceania to further revise the global carbon budget. There are many caveats in our understanding of biogeochemical processes along the land-deep sea continuum, including hadal trenches, mainly because of the indistinguishable complexity of natural and anthropogenic biogeochemical processes that work at almost all climatic components and interfaces of Earth. As wellsaid in Achterberg (2014) and Eglinton (2015), biogeoscientists in general and marine biogeochemists in particular are in the forefront to take-up critical research issues that are related to the current and future global climate changes and climate mitigations in the coming years, as these groups of researchers are dealing with elemental cycles and associated atmospheric gases in diverse land and marine environments from the pole-to-equator-to-pole. Despite the significant methodological advances in recent years such as biomarkers and compoundspecific stable and radiocarbon measurements, doubts/problems of biogeochemical cycles of $\mathrm{C}, \mathrm{N}$ and other elements are still persisting and also hard to reconcile different results from diverse viewpoints and/or methodologies. An integral approach of the chemical characterization of OM with isotopic, biomarker and molecular techniques will be essential in our understanding of biogeochemical cycles of OM and related elements in a changing climate (Bianchi, 2011; Eglinton, 2015). As prescribed, areas of regional priority in the future investigations include the Amazon, the Congo, Yangtze and Yellow riverine basins and their estuaries and tropical coastal currents. The Ganges River system, the Bay of Bengal, the Indonesian Archipelago, the Southeast Asian marginal seas and the Arctic rivers are other critical regions having significantly large carbon inputs into the coastal seas (Regnier et al., 2013) and open ocean.

Climate has long been recognized as an important driver of river carbon supply to the coastal ocean (Bauer et al., 2013; Regnier et al., 2013). Exoreic river basins (i.e., watersheds draining to the seas/oceans) with high precipitation have higher riverine discharge rates, and the discharge in turn is the primary regulator of carbon fluxes (Meybeck, 1982, 1993; Ludwig et al., 1996). It is well known that the global climate has changed dramatically and is still changing with a lot of consequences to the health and survival of 8.74 million species on Earth (Williams et al., 2010). The continuation of global climate change may cause significant shifts in rainfall patterns and storm intensities (IPCC Climate Change, 2013). Based on the interhemispheric temperature asymmetry and its positive trend since 1980s, Friedman et al. (2013) suggested changes in tropical precipitation patterns. They found a tendency to shift tropical rainfall northward in their model simulations and implicated that such a shift in tropical rainfall could increase in monsoon weather systems in Asia or shifts of the wet season from south to north 
in Africa and South America. All these regions are hot spots of sediment and organic carbon production, together sharing the largest sediment $(\sim 50 \%)$ and terrestrial organic carbon $(\sim 60 \%)$ exports to the ocean. Climate models and satellite observations both indicate that the total amount of water in the atmosphere will increase at a rate of $7 \%$ per kelvin of surface warming (Wentz et al., 2007). As the atmosphere warms, one would expect an increase in the integrated water column in the tropics (Knutson et al., 2010), consistent with increased atmospheric moisture content in recent decades in many regions of the world (Trenberth et al., 2005). Therefore, rainfall rates are likely to increase in coming years because of increased intensity of higher storms. For example, the projected magnitude of rainfall is on the order of $+20 \%$ within $100 \mathrm{~km}$ of the tropical cyclone center (Knutson et al., 2010).

As stated above, both a shift in tropical rainfall pattern and a change in storm intensity under a changing climate can alter the continental erosion/weathering rates, which in turn affect riverine exports of mineral particles and DOM and POM to ocean (Allison et al., 2007). River discharge is dominated by low-latitude tropical rivers (Schlünz and Schneider, 2000) and large rivers play a disproportionally important role, as they carry an excessive percentage of fresh water and particulate materials to the oceans (the top 25 rivers supply approximately $50 \%$ of the freshwater and $40 \%$ of the fluvial sediment) (Milliman and Meade, 1983; Milliman and Syvitski, 1992; Milliman and Farnsworth, 2011). Small mountainous rivers in oceanic islands located on the active margin as well as such rivers flowing on the edge of transform active margins (e.g., Eel in California) are

\section{REFERENCES}

Achterberg, E. P. (2014). Grand challenges in marine biogeochemistry. Front. Mar. Sci. 1:7. doi: 10.3389/fmars.2014.00007

Allison, M. A., Bianchi, T. S., McKee, B. A., and Sampere, T. P. (2007). Carbon burial on river-dominated continental shelves: impact of historical changes in sediment loading adjacent to the Mississippi River. Geophys. Res. Lett. 34:L01606. doi: 10.1029/2006gl028362

Altabet, M. A. (2005). "Isotopic tracers of the marine nitrogen cycle Present and Past," The Handbook of Environmental Chemistry Part N, ed J. K. Volkman (Berlin; Heidelberg: Springer-Verlag), 251-293.

Altabet, M. A., and Francois, R. (1994). Sedimentary nitrogen isotopic ratio as a recorder for surface ocean nitrate utilization. Global Biogeochem. Cycles 8, 103-116. doi: 10.1029/93GB03396

Antoine, D., André, J. M., and Morel, A. (1996). Oceanic primary production. 2. Estimation at global scale from satellite (coastal zone color scanner) chlorophyll. Global Biogeochem. Cycles 10, 57-69. doi: 10.1029/95GB02832

Arnosti, C. (2011). Microbial extracellular enzymes and the marine carbon cycle. Ann. Rev. Mar. Sci. 3, 401-425. doi: 10.1146/annurev-marine-120709-142731

Bauer, J. E., Cai, W. J., Raymond, P. A., Bianchi, T. S., Hopkinson, C. S., and Regnier, P. A. G. (2013). The changing carbon cycle of the coastal ocean. Nature 504, 61-70. doi: 10.1038/nature12857

Bauer, J. E., Williams, P. M., and Druffel, E. R. M. (1992). 14C activity of dissolved organic fractions in the central North Pacific and Sargasso Sea. Nature 357, 667-670. doi: 10.1038/357667a0

Berger, W. H., Smetacek, V. S., and Wefer, G. (eds.). (1989). “Ocean productivity and paleoproductivity: an overview," in Productivity of the Ocean: Present and Past (Chichester: Wiley), 1-34.

Berner, R. A. (1982). Burial of organic carbon and pyrite sulfur in the modern ocean: its geochemical and environmental significance. Am. J. Sci. 282, 451-473. doi: 10.2475/ajs.282.4.451 equally important, as these rivers export significant amounts of terrestrial sediment (ca. 50\%; Milliman and Farnsworth, 2011) and organic matter (35\%; Lyons et al., 2002) to the global ocean from a relatively small surface area. Since the global patterns of terrestrial organic carbon shown to reflect broadly different roles of passive and active margin systems in the sedimentary cycle (Blair and Aller, 2012), disentangling the global riverine OC flux and its disproportionate burial in continental shelves are crucial to comprehend the global carbon cycle, which is currently perturbed anthropogenically.

\section{AUTHOR CONTRIBUTIONS}

All authors listed, have made substantial, direct and intellectual contribution to the work, and approved it for publication.

\section{ACKNOWLEDGMENTS}

We are very thankful to the Editor of Frontiers in Marine Science (section: Marine Biogeochemistry) and three reviewers for their constructive feedbacks and insightful suggestions on the original manuscript. SK thanks the National Natural Science Foundation of China (41273083), Shanhai Fund of Xiamen University (2013SH012) and Open Funds of Tongji University (MGK1201) and First Institute of Oceanography (0050-K2015003), China, for the financial support and BN thanks CSIR, India grant for Project GEOSINKS (PSC0106). We also thank Baozhi Lin, Qianqian Liu, and Huawei Wang for their assistance in various stages of the manuscript preparation.

Berner, R. A. (1989). Biogeochemical cycles of carbon and sulfur and their effect on atmospheric oxygen over Phanerozoic time. Palaeogeogr. Palaeoclimatol. Palaeoecol. 75, 97-122. doi: 10.1016/0031-0182(89)90186-7

Berner, R. A. (2004). The Phanerozoic Carbon Cycle: $\mathrm{CO}_{2}$ and $\mathrm{O}_{2}$. New York, NY: Oxford University Press.

Bianchi, T. S. (2011). The role of terrestrially derived organic carbon in the coastal ocean: a changing paradigm and the priming effect. Proc. Natl. Acad. Sci. U.S.A. 108, 19473-19481. doi: 10.1073/pnas.1017982108

Bianchi, T. S., Garcia-Tigreros, F., Yvon-Lewis, S. A., Shields, M., Mills, H. J., Butman, D., et al. (2013). Enhanced transfer of terrestrially derived carbon to the atmosphere in a flooding event. Geophys. Res. Lett. 40, 116-122. doi: 10.1029/2012GL054145

Bird, M. I., Chivas, A. R., and Brunskill, G. J. (1995). Carbon-isotope composition of sediments from the Gulf of Papua. Geo-Mar. Lett. 15, 153-159. doi: 10.1007/BF01204457

Blair, N. E., and Aller, R. C. (2012). The fate of terrestrial organic carbon in the marine environment. Ann. Rev. Mar. Sci. 4, 401-423. doi: 10.1146/annurev-marine-120709-142717

Burdige, D. J. (2005). Burial of terrestrial organic matter in marine sediments: a re-assessment. Global Biogeochem. Cycles 19:GB4011. doi: 10.1029/2004GB 002368

Burdige, D. J. (2007). Preservation of organic matter in marine sediments: controls, mechanisms, and an imbalance in sediment organic carbon budgets? Chem. Rev. 107, 467-485. doi: 10.1021/cr050347q

Carr, M. E., Friedrichs, M. A. M., Schmeltz, M., Aita, M. N., Antoine, D., Arrigo, K., et al. (2006). A comparison of global estimates of marine primary production from ocean color. Deep-sea Res. II, Top. Stud. Oceanogr. 53, 741770. doi: 10.1016/j.dsr2.2006.01.028

Cartapanis, O., Bianchi, D., Jaccard, S. L., and Galbraith, E. D. (2016). Global pulses of organic carbon burial in deep-sea sediments during glacial maxima. Nat. Commun. 7:10796. doi: 10.1038/ncomms10796 
Chen, C. T. A. (2004). "Exchanges of carbon in the coastal Seas," in The Global Carbon Cycle: Integrating Humans, Climate, and the Natural World, SCOPE 62, eds C. B. Field and M. R. Raupach (Washington, DC: Island Press), 341-351.

Ciais, P. C., Sabine, G., Bala, L., Bopp, V., Brovkin, J. Canadell, A., et al. (2013), "Carbon and other biogeochemical cycles, in climate change 2013: the physical science basis," in Contribution of Working Group I to the Fifth Assessment Report of the Intergovernmental Panel on Climate Change, eds T. F. Stocker, D. Qin, G. K. Plattner, M. Tignor, S. K. Allen, J. Boschung, A. Nauels, Y. Xia, V. Bex, and P. M. Midgley (Cambridge, UK; New York, NY: Cambridge University Press), 465-570.

Ciais, P., Tagliabue, A., Cuntz, M., Bopp, L., Scholze, M., Hoffmann, G., et al. (2012). Large inert carbon pool in the terrestrial biosphere during the Last Glacial Maximum. Nat. Geosci. 5, 74-79. doi: 10.1038/ngeo1324

Cole, J. J., Prairie, Y. T., Caraco, N. F., McDowell, W. H., Tranvik, L. J., Striegl, R. G., et al. (2007). Plumbing the global carbon cycle: integrating inland waters into the terrestrial carbon budget. Ecosystems 10, 172-185. doi: 10.1007/s10021-006-9013-8

Cowie, G., Mowbray, S., Kurian, S., Sarkar, A., White, C., Anderson, A., et al. (2014). Comparative organic geochemistry of Indian margin (Arabian Sea) sediments: estuary to continental slope. Biogeosciences 11, 6683-6696. doi: 10.5194/bg-11-6683-2014

Dai, M. H., Yin, Z. Q., Meng, F. F., Liu, Q., and Cai, W. J. (2012). Spatial distribution of riverine DOC inputs to the ocean: an updated global synthesis. Curr. Opin. Environ. Sustain. 4, 170-178. doi: 10.1016/j.cosust.2012. 03.003

Dalzell, B. J., Filley, T. R., and Harbor, J. M. (2005). Flood pulse influences on terrestrial organic matter export from an agricultural watershed. J. Geophys. Res. 110:G02011. doi: 10.1029/2005jg000043

Degens, E. T. (1969). "Biogeochemistry of stable carbon isotopes," in Organic Geochemistry, eds G. Eglinton and M. T. J. Murphy (New York, NY:Springer), 304-328.

Degens, E. T., and Ittekkot, V. (eds.). (1985). "Particulate organic carbon-an overview," in Transport of Carbon and Minerals in Major World Rivers, Lakes and Estuaries (Hamburg: Mitt. Geol. Palaont. Inst. Univ.), 7-27.

Degens, E. T., Kempe, S., and Richey, J. E. (1991). "Summary: biogeochemistry of Major World Rivers," in Biogeochemistry of Major World Rivers, eds E. T. Degens, S. Kempe, and J. Richy (Chichester: Wiley), 323-348.

Dittmar, T., and Kattner, G., (2003). The biogeochemistry of the river and shelf ecosystem of the Arctic Ocean: a review. Mar. Chem. 83, 103-120. doi: 10.1016/ S0304-4203(03)00105-1

Druffel, E. R. M., Honjo, S., Griffin, S., and Wong, C. S. (1986). Radiocarbon in particulate matter from the Eastern Sub-Arctic Pacific Ocean: evidence of a source of terrestrial carbon to the deep sea. Radiocarbon 28, 397-407. doi: $10.1017 /$ S0033822200007517

Dunne, J. P., Sarmiento, J. L., and Gnanadesikan, A. (2007). A synthesis of global particle export from the surface ocean and cycling through the ocean interior and on the seafloor. Global Biogeochem. Cycles 21:GB4006. doi: 10.1029/2006GB002907

Eglinton, E. I., and Repeta, D. J. (2014). "Organic matter in the Contemporary Ocean," in Treatise on Geochemistry, 2nd Edn, Vol. 8, The Oceans and Marine Geochemistry, eds H. Holland and K. Turekian (Amsterdam: Elsevier Ltd), 151-189.

Eglinton, T. I. (2015). Grand challenges in biogeoscience. Front. Ear. Sci. 3:39. doi: $10.3389 /$ feart.2015.00039

Emerson, S., and Hedges, J. I. (1988). Processes controlling the organic carbon content of open ocean sediments. Paleoceanography 3, 621-634. doi: 10.1029/PA003i005p00621

Farrell, J. W., Pedersen, T. F., Calvert, S. E., and Nielsen, B. (1995). Glacialinterglacial changes in nutrient utilization in the equatorial Pacific Ocean. Nature 377, 514-517. doi: 10.1038/377514a0

Field, C., Behrenfeld, M., Randerson, J., and Falkowski, P. (1998). Primary production of the biosphere: integrating terrestrial and oceanic components. Science 281, 237-240. doi: 10.1126/science.281.5374.237

Fogel, M. L., and Cifuentes, L. A. (1993). "Isotope fractionation during primary production," in Organic Geochemistry, eds S. A. Macko and M. H. Engel (New York, NY:Springer), 73-98.
Francois, R., Altabet, M. A., and Buckle, L. H. (1992). Glacial to interglacial changes in surface nitrate utilization in the Indian sector of the Southern Ocean as recorded by sediment $\delta 15 \mathrm{~N}$. Paleoceanography 7, 589-606. doi: 10.1029/92PA01573

Friedman, A. R., Hwang, Y. T., Chiang, J. C. H., and Frierson, D. M. W. (2013). Interhemispheric temperature asymmetry over the twentieth century and in future Projections. J. Climate 26, 5419-5433. doi: 10.1175/JCLI-D-1200525.1

Galimov, E. M. (2006). Isotopic organic geochemistry. Org. Geochem. 37, 12001262. doi: 10.1016/j.orggeochem.2006.04.009

Galy, V., Beyssac, O., France-Lanord, C., and Eglinton, T. I. (2008). Recycling of graphite during Himalayan erosion: a geological stabilization of carbon in the crust. Science 322, 943-945. doi: 10.1126/science.1161408

Galy, V., France-Lanord, C., Beyssac, O., Faure, P., Kudrass, H., and Palhol, F. (2007). Efficient organic carbon burial in the Bengal fan sustained by the Himalayan erosional system. Nature 450, 407-410. doi: 10.1038/nature 06273

Gearing, P., Plucker, F. E., and Parker, P. L. (1977). Organic carbon stable isotope ratios of continental marine sediments. Mar. Chem. 5, 251-266. doi: 10.1016/0304-4203(77)90020-2

Glud, R. N., Wenzhöfer, F., Middleboe, M., Oguri, K., Turnewitsch, R., Canfield, D. E., et al. (2013). High rates of microbial carbon turnover in sediments in the deepest oceanic trench on Earth. Nat. Geosci. 6, 284-288. doi: $10.1038 /$ ngeo1773

Godsey, S. E., Krichner, J. W., and Clow, D. W. (2009). Concentration-discharge relationships reflect chemostatic characteristics of US catchments. Hydrol. Process. 23, 1844-1864. doi: 10.1002/hyp.7315

Goñi, M. A., Hatten, J. A., Wheatcroft, R. A., and Borgeld, J. C. (2013). Particulate organic matter export by two contrasting small mountainous rivers from the Pacific Northwest, U.S.A. J. Geophys. Res. Biogeosci. 118. 112-134. doi: 10.1002 /jgrg. 20024

Goñi, M. A., Moore, E., Kurtz, A., Portier, E., Alleau, Y., and Merrell, D. (2014). Organic matter compositions and loadings in soils and sediments along the Fly River, Papua New Guinea. Geochim. Cosmochim. Acta 140, 275-296. doi: 10.1016/j.gca.2014.05.034

Goñi, M. A., Ruttenberg, K. C., and Eglinton, T. I. (1997). Sources and contribution of terrigenous organic carbon to surface sediments in the Gulf of Mexico. Nature 389, 275-278. doi: 10.1038/38477

Goñi, M. A., Ruttenberg, K. C., and Eglinton, T. I. (1998). A reassessment of the sources and importance of land-derived organic matter in surface sediments from the Gulf of Mexico. Geochim. Cosmochim. Acta 62, 3055-3075. doi: 10.1016/S0016-7037(98)00217-8

Goldsmith, S. T., Carey, A. E., Lyons, W. B., Kao, S. J., Lee, T. Y., and Chen, J. (2008). Extreme storm events, landscape denudation, and carbon sequestration: typhoon Mindulle, Choushui River, Taiwan. Geology 36, 483-486. doi: 10.1130/G24624A.1

Gruber, N., Friedlingstein, P., Field, C. B., Valentini, R., Heimann, M., Richey, J. E., et al. (2004). "The vulnerability of the carbon cycle in the 21st century: an assessment of carbon-climate-human interactions," in The Global Carbon Cycle: Integrating Human, Climate and the Natural World, eds C. B. Field and M. R.Raupach (Washington, DC: Scope) 45-77.

Gruber, N., and Galloway, J. N. (2008). An Earth-system perspective of the global nitrogen cycle. Nature 451, 293-296. doi: 10.1038/nature 06592

Guggenberger, G., and Kaiser, K. (2003). Dissolved organic matter in soil: challenging the paradigm of sorptive preservation. Geoderma 113, 293-310. doi: 10.1016/S0016-7061(02)00366-X

Guidi, L., Legendre, L., Reygondeau, G., Uitz, J., Stemmann, L., and Henson, S. A. (2015). A new look at ocean carbon remineralization for estimating deepwater sequestration. Global Biogeochem. Cycles 29, 1044-1059. doi: 10.1002/2014GB005063

Hedges, J. I. (1992). Global biogeochemical cycles: progress and problems. Mar. Chem. 39, 67-93. doi: 10.1016/0304-4203(92)90096-S

Hedges, J. I., Cowie, G. L., Richey, J. E., Quay, P. D., Benner, R., Strom, M., et al. (1994). Origins and processing of organic matter in the Amazon River as indicated by carbohydrates and amino acids. Limnol. Oceanogr. 39, 743-761. doi: 10.4319/lo.1994.39.4.0743 
Hedges, J. I., and Keil, R. G. (1995). Sedimentary organic matter preservation: an assessment and speculative synthesis. Mar. Chem. 49, 81-115. doi: 10.1016/0304-4203(95)00008-F

Hedges, J. I., Keil, R. G., and Benner, R. (1997). What happens to terrestrial organic matter in the ocean? Org. Geochem. 27, 195-212. doi: 10.1016/S0146-6380(97)00066-1

Hedges, J. I., and Mann, D. C. (1979). The lignin geochemistry of marine sediments from the southern Washington coast. Geochim. Cosmochim. Acta 43, 1809-1818. doi: 10.1016/0016-7037(79)90029-2

Henson, S. A., Sanders, R., and Madsen, E. (2012). Global patterns in efficiency of particulate organic export and transfer to the deep ocean. Global Biogeochem. Cycles 26, GB1028. doi: 10.1029/2011GB004099

Hilton, R. G., Galy, A., Hovius, N., Chen, M. C., Horng, M. J., and Chen, H. (2008). Tropical-cyclone-driven erosion of the terrestrial biosphere from mountains. Nat. Geosci. 1, 759-762. doi: 10.1038/ngeo333

Hope, D., Billett, M. F., and Cresser, M. S. (1994). A review of the export of carbon in river water: fluxes and processes. Environ. Pollut. 84, 301-324. doi: 10.1016/0269-7491(94)90142-2

Houghton, R. A. (2007). Balancing the global carbon budget. Annu. Rev. Earth Planet. Sci. 35, 313-347. doi: 10.1146/annurev.earth.35.031306.140057

Huang, T. H., Fu, Y. H., Pan, P. Y., and Chen, C. T. A. (2012). Fluvial carbon fluxes in tropical rivers. Curr. Opin. Environ. Sustain. 4, 162-169. doi: 10.1016/j.cosust,.2012.02.004

IPCC Climate Change (2013). "The physical science basis," in Contribution of Working Group I to the Fifth Assessment Report of the Intergovernmental Panel on Climate Change, eds T. F. Stocker, D. Qin, G.-K. Plattner, M. Tignor, S. K. Allen, J. Boschung, A. Nauels, Y. Xia, V. Bex, and P. M. Midgley (Cambridge University Press), 1-1535.

Ittekkot, V., and Arain, R. (1986). Nature of particulate organic matter in the river Indus, Pakistan. Geochim. Cosmochim. Acta 50, 1643-1653. doi: 10.1016/0016-7037(86)90127-4

Ittekkot, V., Safiullah, S., Mycke, B., and Seifert, R. (1985). Seasonal variability and geochemical significance of organic matter in the River Ganges, Bangladesh. Nature 317, 800-802. doi: 10.1038/317800a0

Jamieson, A. J., Fujii, T., Mayor, D. J., Solan, M., and Priede, I. G. (2010). Hadal trenches: the ecology of the deepest places on Earth. Trends Ecol. Evol. 25, 190-197. doi: 10.1016/j.tree.2009.09.009

Kao, S. J., Hilton, R. G., Selvaraj, K., Dai, M., Zehetner, F., Huang, J. C., et al. (2014). Preservation of terrestrial organic carbon in marine sediments offshore Taiwan: mountain building and atmosphere carbon dioxide sequestration. Earth Surf. Dynam. 2, 127-139. doi: 10.5194/esurf-2-127-2014

Kao, S. J., and Milliman, J. D. (2008). Water and sediment discharges from small mountainous rivers, Taiwan: the roles of lithology, episodic events, and human activities. J. Geol. 116, 431-448. doi: 10.1086/590921

Keil, R. G., and Mayer, L. M. (2014). "Mineral matrices and organic matter," in Treatise on Geochemistry, 2nd Edn, Vol. 12, Organic Geochemistry, eds H. Holland and K. Turekian (Amsterdam: Elsevier Ltd), 337-359.

Keil, R. G., Tsamakis, E., Wolf, N., Hedges, J. I., and Go-i, M. (1997). "Relationships between organic carbon preservation and mineral surface area in Amazon Fan sediments (Holes 932A and 942A)," in Proceedings of the Ocean Drilling Program, Scientific Results, Vol. 155 (Texas), 531-538.

Kennedy, M. J., and Wagner, T. (2010). Clay mineral continental amplifier for marine carbon sequestration in a greenhouse ocean. Proc. Natl. Acad. U.S.A. 108, 9776-9781. doi: 10.1073/pnas. 1018670108

Knutson, T. R., McBride, J. L., Chan, J., Emanuel, K., Holland, G., Landsea, C., et al. (2010). Tropical cyclones and climate change. Nat. Geosci. 3, 157-163. doi: $10.1038 /$ ngeo 779

Kurian, S., Nath, B. N., Kumar, N. C., and Nair, K. K. C. (2013). Geochemical and isotopic signatures of surficial sediments from the western continental shelf of India: inferring provenance, weathering, and the nature of organic matter. J. Sed. Petrol. 83, 427-442. doi: 10.2110/jsr.2013.36

Leri, A. C., Hakala, J. A., Marcus, M. A., Lanzirotti, A., Reddy, C. M., and Myneni, S. C. B. (2010). Natural organobromine in marine sediments: New evidence of biogeochemical Br cycling. Global Biogeochem. Cycles 24, GB4017. doi: 10.1029/2010GB003794
Leri, A. C., Mayer, L. M., Thornton, K. R., Northrup, P. A., Dunigan, M. R., Ness, K. J., et al. (2015). A marine sink for chlorine in natural organic matter. Nat. Geosci. 8, 620-624. doi: 10.1038/ngeo2481

Leri, A. C., Mayer, L. M., Thornton, K. R., and Ravel, B. (2014). Bromination of marine particulate organic matter through oxidative mechanisms. Geochim. Cosmochim. Acta 142, 53-63. doi: 10.1016/j.gca.2014.08.012

Leri, A. C., and Myneni, S. (2012). Natural organobromine in terrestrial ecosystems. Geochim. Cosmochim. Acta 77, 1-10. doi: 10.1016/j.gca.2011.11.012

Liu, K. K., Iseki, K., and Chao, S. Y. (2000). "Continental margin carbon fluxes," in The Changing Ocean Carbon Cycle, eds R. B. Hanson, H. W. Ducklow, and J. G. Field (New York, NY: Cambridge University Press), 187-240.

Liu, K. K., and Kaplan, I. R. (1989). The eastern tropical Pacific as a source of $15 \mathrm{~N}$-enriched nitrate in seawater off southern California. Limnol. Oceanogr. 34, 820-830. doi: 10.4319/lo.1989.34.5.0820

Ludwig, W., Probst, J. L., and Kempe, S. (1996). Predicting the oceanic input of organic carbon by continental erosion. Global Biogeochem. Cycles 10, 23-41. doi: 10.1029/95GB02925

Lyons, W. B., Nezat, C. A., Carey, A. E., and Hicks, D. M. (2002). Organic carbon fluxes to the ocean from high-standing islands. Geology 30, 439-442. doi: 10.1130/0091-7613(2002)030<0443:OCFTTO > 2.0.CO;2

Mackenzie, F. T., Ver, L. M., Sabine, C., Lane, M., and Lerman, A. (1993). “C, N, P, $S$ global biogeochemical cycles and modeling of global change," in Interactions of C, N, P and S Biogeochemical Cycles and Global Change, eds R. Wollast, F. T. Mackenzie, and L. Chou (Berlin; Heidelberg: Springer), 1-61.

Mayer, L. M., Macko, S. A., Mook, W. H., and Murray, S. M. (1981). The distribution of bromine in coastal sediments and its use as a source indicator for organic matter. Org. Geochem. 3, 37-42. doi: 10.1016/0146-6380(81)90011-5

Mayer, L. M., Schick, L., Hardy, K., Wagai, R., and McCarthy, J. (2004). Organic matter content of small mesopores in sediments and soils. Geochim. Cosmochim. Acta 68, 3863-3872. doi: 10.1016/j.gca.2004.03.019

Mayer, L. M., Schick, L. L., Allison, M. A., Ruttenberg, K. C., and Bentley, S. J. (2007). Marine vs. terrigenous organic matter in Louisiana coastal sediments: the uses of bromine:organic carbon ratios. Mar. Chem. 107, 2442-2454. doi: $10.1016 /$ j.marchem.2007.07.007

McClelland, J. W., Holmes, R. M., Peterson, B. J., Raymond, P. A., Striegl, R. G., Zhulidov, A. V., et al. (2016). Particulate organic carbon and nitrogen export from major Arctic Rivers. Global Biogeochem. Cycles 30, 629-643. doi: 10.1002/2015GB005351

McKee, B. A. (2003). "RiOMar: The Transport, Transformation and Fate of Carbon," in River-dominated Ocean Margins: A Report of the RioMar Community Workshop, 1-3 November 2001 (Tulane University, New Orleans, LA: Tulane University), Available online at: http://www.tulane.edu/ riomar/

Meybeck, M. (1982). Carbon, nitrogen and phosphorous transport by world rivers. Am. J. Sci. 282, 401-450. doi: 10.2475/ajs.282.4.401

Meybeck, M. (1993). "C, N, P and S in rivers: from sources to global inputs," in Interactions of $\mathrm{C}, \mathrm{N}, \mathrm{P}$ and S: Biogeochemical Cycles and Global Change, (Berlin; Heidelberg; New York, NY: Springer), 163-193.

Meybeck, M., and Vörösmarty, C. (1999). Global transfer of carbon by rivers. Global Change Newslett. 37, 18-19.

Meyers, P. A. (1994), Preservation of elemental and isotopic source identification of sedimentary organic matter. Chem. Geol. 114, 289-302.

Meyers, P. A. (2014). Why are the $\delta^{13} \mathrm{C}_{\text {org }}$ values in Phanerozoic black shales more negative than in modern marine organic matter? Geochem. Geophys. Geosyst. 15, 3085-3106. doi: 10.1002/2014GC005305

Milliman, J. D., and Farnsworth, K. L. (2011). River Discharge to the Coastal Ocean: A Global Synthesis. Cambridge: Cambridge University Press.

Milliman, J. D., and Meade, R. H. (1983). World-wide delivery of river sediment to the oceans. J. Geol. 91, 1-21. doi: 10.1086/628741

Milliman, J. D., and Syvitski, J. P. M. (1992). Geomorphic/tectonic control of sediment discharge to the ocean: the importance of small mountainous rivers. J. Geol. 100, 525-544. doi: 10.1086/629606

Mollenhauer, G., Schneider, R. R., Jennerjahn, T., Müller, P. J., and Wefer, G. (2004). Organic carbon accumulation in the South Atlantic Ocean: its modern, mid-Holocene and last glacial distribution. Global Planet. Change 40, 249-266. doi: 10.1016/j.gloplacha.2003.08.002

Muller-Karger, F. E., Varela, R., Thunell, R., Luerssen, R., Hu, C., and Walsh, J. J. (2005). The importance of continental margins in the 
global carbon cycle. Geophys. Res. Lett. 32:L01602. doi: 10.1029/2004gl0 21346

Newman, J. W., Parker, P. L., and Behrens, E. W. (1973). Organic carbon ratios in Quaternary cores from the Gulf of Mexico. Geochim. Cosmochim. Acta 37, 225-238. doi: 10.1016/0016-7037(73)90130-0

Nunoura, T., Takaki, Y., Hirai, M., Shimamura, S., Makabe, A., Koide, O., et al. (2015). Hadal biosphere: insight into the microbial ecosystem in the deepest ocean on Earth. Proc. Natl. Acad. Sci. U.S.A. E1230-E1236. doi: $10.1073 /$ pnas. 1421816112

Nuwer, J. M., and Keil, R. G. (2005). Sedimentary organic matter geochemistry of Clayoquot Sound, Vancouver Island, British Columbia. Limnol. Oceanogr. 50, 1119-1128. doi: 10.4319/lo.2005.50.4.1119

Peña, A., Lewis, M. R., and Cullen, J. J. (1994). New production in the warm waters of the tropical Pacific Ocean. J. Geophys. Res. 99, 14255-14268. doi: 10.1029/94JC00603

Prahl, F. G., and Muehlhausen, L. A. (1989). "Lipid biomarkers as geochemical tools for paleo-oceanographic study," in Productivity of the Ocean: Present and Past, eds W. H. Berger, V. S. Smetacek and G. Wefer (Berlin: Wiley), 271-289.

Raymond, P. A., and Bauer, J. E. (2001). Use of $14 \mathrm{C}$ and $13 \mathrm{C}$ natural abundance for evaluating riverine, estuarine, and coastal DOC and POC sources and cycling: a review and synthesis. Org. Geochem. 32, 469-485. doi: 10.1016/S0146-6380(00)00190-X

Raymond, P. A., and Oh, N.-H. (2007). An empirical study of climatic controls on riverine C export from three major U.S. watersheds. Global Biogeochem. Cycles 21:GB2022. doi: 10.1029/2006GB002783

Raymond, P. A., and Saiers, J. E. (2010). Event controlled DOC export from forested watersheds. Biogeochemistry 100, 197-209. doi: 10.1007/s10533-010-9416-7

Regnier, P., Friedlingstein, P., Ciais, P., Mackenzie, F. T., Gruber, N., Janssens, I. A., et al. (2013). Anthropogenic perturbation of the carbon fluxes from land to ocean. Nat. Geosci. 6, 597-607. doi: 10.1038/ngeo 1830

Romankevich, E. A. (1984). Geochemistry of Organic Matter in the Ocean. Berlin; Heidelberg; New York: Springer.

Sarmiento, J. L., and Gruber, N. (2002). Sinks for anthropogenic carbon. Phys. Today 55, 30-36. doi: 10.1063/1.1510279

Schlünz, B., and Schneider, R. R. (2000). Transport of terrestrial organic carbon to the oceans by rivers: re-estimating flux- and burial rates. Int. J. Earth Sci. 88, 599-606. doi: 10.1007/s005310050290

Schlünz, B., Schneider, R. R., Müller, P. J., Showers, W. J., and Wefer, G. (1999). Terrestrial organic carbon accumulation on the Amazon deep sea fan during the last glacial sea level low stand. Chem. Geol. 159, 263-281. doi: 10.1016/S0009-2541(99)00041-8

Schubert, C. J., and Calvert, S. E. (2001). Nitrogen and carbon isotopic composition of marine and terrestrial organic matter in Arctic Ocean sediments: implications for nutrient utilization and organic matter composition. Deep-Sea Res. I 48, 789-810. doi: 10.1016/S0967-0637(00)00069-8

Seitzinger, S. P., Harrison, J. A., Dumont, E., Beusen, A. H. W., and Bouwman, A. F. (2005). Sources and deliver of carbon, nitrogen, and phosphorous to the coastal zone: an overview of Global Nutrient Export from Watersheds (NEWS) models and their application. Global Biogeochem. Cycles 19:GB4S01. doi: 10.1029/2005GB002606

Selvaraj, K., Lee, T. Y., Yang, J. Y. T., Canuel, E. A., Huang, J. C., Dai, M., et al. (2015). Stable isotopic and biomarker evidence of terrigenous organic matter export to the deep sea during tropical storms. Mar. Geol. 364, 32-42. doi: 10.1016/j.margeo.2015.03.005

Smith, R. W., Bianchi, T. S., Allison, M., Savage, C., and Galy, V. (2015). High rates of organic carbon burial in fjord sediments globally. Nat. Geosci. 8, 450-454. doi: $10.1038 /$ ngeo 2421

Smith, S. V., and Mackenzie, F. T. (1987). The ocean as a net heterotrophic system: implications from the carbon biogeochemical cycle. Global Biogeochem. Cycles 1, 187-198. doi: 10.1029/GB001i003p00187

Spitzy, A., and Ittekkot, V. (1991). "Dissolved and particulate organic matter in rivers," in Ocean Margin Processes in Global Change, eds R. F. C. Mantoura, J. M. Martin, and R. Wollast (Chichester: Wiley), 5-17.
Rachold, V., Eicken, H., Gordeev, V. V., Grigoriev, M. N., Hubberten, H.W., Lisitzin, A. P., et al. (2004). "Modern terrigenous organic carbon input to the Arctic Ocean," in The Organic Carbon Cycle in the Arctic Ocean, eds R. S. Stein and R. W. Macdonald (New York, NY: Springer), 33-55.

Sundquist, E. T. (1986). "Geologic analogs: their value and limitations in carbon dioxide research," in The Changing Carbon Cycl, eds J. R. Trabalka and D. E. Reichle (New York, NY: Springer-Verlag), 317-402.

Syvitski, J. P. M., Vörösmarty, C. J., Kettner, A. J., and Green, P. (2005). Impact of humans on the flux of terrestrial sediment to the global coastal ocean. Science 308, 376-380. doi: 10.1126/science.1109454

Tesi, T., Semiletov, I., Hugelius, G., Dudarev, O., Kuhry, P., and Gustafsson, Ö. (2014). Composition and fate of terrigenous organic matter along the Arctic land-ocean continuum in East Siberia: insights from biomarkers and carbon isotopes. Geochim. Cosmochim. Acta 133, 235-256. doi: 10.1016/j.gca.2014.02.045

Trenberth, K., Fasullo, J., and Smith, L. (2005). Trends and variability in column-integrated atmospheric water vapor. Clim. Dynam. 24, 741-758. doi: 10.1007/s00382-005-0017-4

Vörösmarty, C. J., Meyback, M., Fekete, B., Sharma, K., Green, P., and Syvitski, J. P. M. (2003). Anthropogenic sediment retention: major global impact from registered river impoundments. Global Planet. Change 39, 169-190. doi: 10.1016/S0921-8181(03)00023-7

Wada, E., and Hattori, A. (1976). Natural abundance of $15 \mathrm{~N}$ in particulate organic matter in the North Pacific Ocean. Geochim. Cosmochim. Acta 40, 249-251. doi: 10.1016/0016-7037(76)90183-6

Wada, E., and Hattori, A. (1991). Nitrogen in the Sea: Forms, Abundances and Rate Processes. Ann Arbor, MI: CRC Press.

Walling, D. E. (2009). The Impact of Global Change on Erosion and Sediment Transport by Rivers: Current Progress and Future Challenges. The United Nations World Water Development Report 3 Water in a Changing World, 1-30.

Wentz, F. J., Ricciardulli, L., Hilburn, K., and Mears, C. (2007). How much more rain will global warming bring? Science 317, 233-235. doi: 10.1126/science. 1140746

Whitman, W. B., Coleman, D. C., and Wiebe, W. J. (1998). Prokaryotes: the unseen majority. Proc. Natl. Acad. Sci. U.S.A. 95, 6578-6583. doi: 10.1073/pnas.95.12.6578

Williams, M. J., Ausubel, J., Poiner, I., Garcia, S. M., Baker, D. J., Clark, M. R., et al. (2010). Making marine life count: a new baseline for policy. PLoS Biol. 8:e1000531. doi: 10.1371/journal.pbio.1000531

Wollast, R. (1991). The Coastal Organic Carbon Cycle: Fluxes, Sources and Sinks, in Ocean Margin Processes in Global Change. Chichester: Wiley.

Yoon, B., and Raymond, P. A. (2012). Dissolved organic matter export from a forested watershed during Hurricane Irene. Geophys. Res. Lett. 39:L18402. doi: 10.1029/2012GL052785

Zafiriou, O. C., Gagosian, R. B., Peltzer, E. T., Alford, J. B., and Loder, T. (1985). Air-to-sea fluxes of lipids at Enewetak Atoll. J. Geophys. Res. 90, 2409-2423. doi: 10.1029/JD090iD01p02409

Zeng, N. (2003). Glacial-interglacial atmospheric CO2 change - The glacial burial hypothesis. Adv. Atmos. Sci. 20, 677-693. doi: 10.1007/BF02915395

Conflict of Interest Statement: The authors declare that the research was conducted in the absence of any commercial or financial relationships that could be construed as a potential conflict of interest.

The reviewer AS and handling Editor declared their shared affiliation, and the handling Editor states that the process nevertheless met the standards of a fair and objective review.

Copyright (c) 2016 Kandasamy and Nagender Nath. This is an open-access article distributed under the terms of the Creative Commons Attribution License (CC BY). The use, distribution or reproduction in other forums is permitted, provided the original author(s) or licensor are credited and that the original publication in this journal is cited, in accordance with accepted academic practice. No use, distribution or reproduction is permitted which does not comply with these terms. 